\title{
Happiness and quality of city life. The case of Milan, the richest Italian city ${ }^{1}$
}

\author{
Alessandro Balducci, Dept. Architecture and Planning, Politecnico di Milano \\ Daniele Checchi, Dept. Economics, State University of Milan, \\ this version: $5 / 10 / 2008$
}

\section{INTRODUCTION}

There is a growing economic literature on the determinants of subjective well-being, ${ }^{2}$ which usually includes wealth or income, health status, occupations, marital conditions and education among their main determinants (Layard 1980, Frey and Stutzer 2002, DiTella and McCulloch 2006). ${ }^{3}$ Subjective measures have been validated as good indicators of individual well being by psychologist, sociologists and more recently economists (Diener et al 1999). Most of the economic analysis has been concerned to what is known as the Easterlin paradox, originally emerged in cross-countries comparisons, i.e. the finding of similar levels of happiness in poor and rich countries (Easterlin 1974 and 2001). Similarly, in representative samples of individual data, the relationship between various measures of life satisfaction and income has proved to be concave, i.e. there is a decreasing marginal utility of income: doubling the income level of a person raises individual satisfaction less than twofold (Layard et al. 2008). When longitudinal data exists, allowing the inclusion of individual fixed effects, it is often found that there is significant heterogeneity in individual attitudes about life (Clark et al. 2006). Previous research has not found strong links between level of income and level of happiness, which has been rationalised by decreasing marginal utility of income, adaptive aspirations, interpersonal comparisons of well-being and endogenous (culturally determined) preferences (Layard 1980 and 2006).

The relationship between subjective well-being and the quality of city life is still rather unexplored. Information about local amenities such as climate, environmental and urban conditions are difficult to collect in surveys on representative samples. When these data are available, they prove that locationspecific factors (like excess noise levels, air pollution and climate) have a direct impact on life satisfaction (Brereton et al. 2006).

Only very recently the relationship between quality of places and happiness has been explored by the inventor of the "creative class" Richard Florida, in a book where which he extensively inquires about the role of places in determining personal achievement. The main message of this new book is not only the quality of the places where we live affects our happiness but also the kind of place where we live is a key factor for the personal success of creative people (Florida 2008). ${ }^{4}$

Two potential reasons may explain this lack of analysis. The first one relates to the difficulty to provide quantitative measurement of what is meant by "quality of life", which typically mixes objective measures (like pollution, traffic, availability of public services) with subjective perceptions (related to

\footnotetext{
${ }^{1}$ A preliminary version of the current paper was presented to the first meeting of the Global Metropolitan Forum of Seoul on "Assessing happiness and competitiveness of world major metropolitan areas", held in Seoul (19/01/2007). We thank the Metropolitan Forum for making the individual data used in the empirical analysis available to us. We also thank the editor of the Journal for helpful suggestions.

2 We use interchangeably "subjective well-being", "life satisfaction" and "happiness". For the exact wording of these questions in most known opinion surveys see Layard et al. 2008.

3 An unsolved (and unsolvable) question in this literature concerns the causality between happiness perception and various life events. For example, it is well-known that events such as unemployment and marriage have large and significant crosssection correlations with various measures of subjective well-being. But the converse may also be true: unsatisfied people are more likely to loose their jobs and/or to break their affective relationships. For this reason, in the sequel we will speak of correlations and not of causal impacts.

4 The empirical evidence of Florida 2008 is obtained from the correlation between "overall place satisfaction" and/or "city satisfaction" with various factors (aesthetics and lifestyle, basic services, openness, economic and personal security) among US cities.
} 
security, interpersonal relationships, life styles). The second one is that life satisfaction has an implicit component of interpersonal comparison: when my consumption increases at the same rate of the consumption of other people living around me, my level of satisfaction may remain constant. However the dimension of externalities is hard to control, because it would require collecting information not at individual level but at community level. Since an urban area merges rich and poor people living together, each of them with their own perception of the city life, it is hard to disentangle empirical regularities in the associations between (subjectively perceived) dimensions of urban life and (subjectively perceived) level of well-being. Even controlling for individual social status does not help to sort out the matter.

This problem becomes endemic in the comparison of the relationship between quality of life and happiness across different cities (or countries). However, the expanding literature on cross-countries comparisons of the association between income and happiness has provided significant insights not on levels of happiness (which remain not comparable across countries, due to historical, religious and cultural differences) but on different patterns of association between well-being and material resources, depending on the level of development of a country (including social networks and social capital Clark et al. 2006). We aim to replicate a similar exercise with respect to quality of urban life. As long as we are able to construct proxy measures for the quality of city life, we can study how these measures are correlated with a subjectively expressed measure of well-being. As long as these associations are statistically robust, one can go on and speculate on the role of public policies in shaping the well-being of its citizenship.

In the sequel we use data for a survey conducted in 2006 in a comparable way across ten metropolitan cities in the developed world, and we explore the subjective perception of happiness and its association with different aspects of city life. In particular we explore which dimensions are perceived as more strongly associated to individual happiness, under a unique world-wide model of determination. We then explore whether there are deviations from this univocal pattern of association, and we provide a case-study for Milan, one of the richest and internationally oriented Italian cities. Contrary to cliché perception about Italians, Milan inhabitants express one of the lowest level of satisfaction (comparable to Tokyo or Beijing), despite their high levels of income and employment. Our suggested explanation is that the dramatic change which occurred in the last 30 years in the form and structure of the urban area (enlargement, de-industrialisation, increasing mobility, immigration, loss of population, polarisation, etc.) has brought about a worsening of the living conditions perceived by Milan's residents. We provide indirect evidence on demography, residence and land exploitation that are consistent with this interpretation.

\section{HAPPINESS ACROSS WORLD CITIES}

We make use of a new dataset, the "Quality of Life Survey", which has been conducted in ten metropolitan areas in the world. "The survey has been conducted in December 2006, and has been commissioned by the Metropolitan Government of Seoul, which was interested in assessing the satisfaction of local inhabitants, comparatively with other citizens in other big cities. The questionnaire, reported in Appendix 2, asks opinions about the interviewees' perceptions of different aspects of city life: economy, culture and education, welfare, safety, environment, city administration and community life. It also includes standard demographic information about gender, age, educational attainment, selfassessed income position, occupation, religion, health and marital status. On top of this, two questions relate to the pride of living in the city and to subjectively perceived level of happiness.

From each city included in the project, the data collectors interviewed a sample of one thousand individuals, aged 18 or older. The descriptive statistics of some demographics are reported in table 1 and 2, where we provide information over the distribution of educational attainments, income status and some occupational categories. Since the sample is stratified by gender and age, we do not observe

\footnotetext{
${ }^{5}$ The sample includes Seoul, New York City, Toronto, London, Paris, Berlin, Milan, Tokyo, Beijing and Stockholm.
} 
significant sample distortions over these two dimensions, yet these cities are quite different in terms of educational attainments. While more than half of the population attains a college degree in North America and Scandinavia, one third of the adult population does not achieve a secondary school degree in Milan and Berlin. Unfortunately, the survey does not collect objective measures of income, but only subjective assessment of income relative position. The distribution of educational attainment may be only partially suggestive of the actual income distribution, since the return to education may vary across countries according to labour market institutions (like minimum wages, wage compression, bargaining coverage). However, if the subjective assessment may be informative though asked in relative terms, we notice from table 2 that income poverty (both in terms of income level and unemployment risk) is highest in Beijing and London and lowest in Tokyo. ${ }^{6}$ There are clearly unavoidable cultural differences between countries, as witnessed by women participation to the labour market: the fraction of women self-declaring as housewife is as high as 30\% in Seoul or Tokyo, as well as nil in Stockholm.

Table 1 - Descriptive statistics - Age, gender and educational attainment - percentage

\begin{tabular}{|l||c||c|c|c|c|c|c|c|c|c||}
\hline & $\begin{array}{c}\text { fraction } \\
\text { of } \\
\text { women }\end{array}$ & $\begin{array}{c}\text { average } \\
\text { age } \\
\text { (years) }\end{array}$ & $\begin{array}{c}\text { no } \\
\text { education }\end{array}$ & $\begin{array}{c}\text { primary } \\
\text { school } \\
\text { completed } \\
\text { (6th } \\
\text { grade) }\end{array}$ & $\begin{array}{c}\text { junior high } \\
\text { school } \\
\text { completed } \\
\text { (9th } \\
\text { grade) }\end{array}$ & $\begin{array}{c}\text { high } \\
\text { school } \\
\text { completed } \\
\text { (12th } \\
\text { grade) }\end{array}$ & $\begin{array}{c}\text { trade/ } \\
\text { vocational } \\
\text { school } \\
\text { completed }\end{array}$ & $\begin{array}{c}\text { college/ } \\
\text { university } \\
\text { student }\end{array}$ & $\begin{array}{c}\text { college } \\
\text { luniversity } \\
\text { completed } \\
\text { or above }\end{array}$ & $\begin{array}{c}\text { sample } \\
\text { size }\end{array}$ \\
\hline Seoul & 51.90 & 44.10 & 2.06 & 4.84 & 8.33 & 28.81 & 0.00 & 12.65 & 43.31 & 1000 \\
\hline New York & 52.50 & 45.16 & 0.41 & 0.62 & 2.87 & 29.06 & 1.85 & 8.73 & 56.47 & 1000 \\
\hline Toronto & 53.10 & 44.34 & 0.60 & 0.81 & 3.42 & 22.66 & 3.63 & 9.26 & 59.62 & 1000 \\
\hline London & 51.00 & 42.79 & 2.47 & 2.26 & 2.16 & 35.80 & 6.58 & 5.04 & 45.68 & 1000 \\
\hline Paris & 51.30 & 43.38 & 1.22 & 3.56 & 6.51 & 40.39 & 9.56 & 8.85 & 29.91 & 1000 \\
\hline Berlin & 50.50 & 43.72 & 1.94 & 10.09 & 21.41 & 24.06 & 12.03 & 7.54 & 22.94 & 1000 \\
\hline Milan & 50.79 & 45.51 & 0.20 & 8.01 & 23.15 & 33.14 & 8.41 & 6.03 & 21.07 & 1014 \\
\hline Tokyo & 49.60 & 45.57 & 0.00 & 0.50 & 4.33 & 23.56 & 14.40 & 4.03 & 53.17 & 1000 \\
\hline Beijing & 49.60 & 40.80 & 1.91 & 3.42 & 18.79 & 27.84 & 7.74 & 13.97 & 26.33 & 1000 \\
\hline Stockholm & 50.90 & 43.81 & 0.10 & 2.30 & 5.81 & 22.14 & 11.42 & 6.31 & 51.90 & 1000 \\
\hline $\begin{array}{l}\text { Entire } \\
\text { sample }\end{array}$ & 51.12 & 43.92 & 1.08 & 3.65 & 9.72 & 28.73 & 7.59 & 8.24 & 40.99 & 10014 \\
\hline
\end{tabular}

Source: our elaboration from GMFS survey (2006)

Table 2 - Descriptive statistics - Income status, occupation and unemployment rate - percentage

\begin{tabular}{|l||c|c|c|c|c|c|c|c|c|c||c|}
\hline & $\begin{array}{c}\text { very low } \\
\text { income }\end{array}$ & $\begin{array}{c}\text { low } \\
\text { income }\end{array}$ & $\begin{array}{c}\text { middle } \\
\text { income }\end{array}$ & $\begin{array}{c}\text { high } \\
\text { income }\end{array}$ & $\begin{array}{c}\text { very high } \\
\text { income }\end{array}$ & $\begin{array}{c}\text { profess } \\
\text { ionals }\end{array}$ & $\begin{array}{c}\text { white } \\
\text { collars }\end{array}$ & $\begin{array}{c}\text { blue } \\
\text { collars } \\
\text { (manual+ } \\
\text { skilled) }\end{array}$ & $\begin{array}{c}\text { self- } \\
\text { employed }\end{array}$ & $\begin{array}{c}\text { house } \\
\text { wife }\end{array}$ & $\begin{array}{l}\text { umenploy } \\
\text { ment rate } \\
\text { (age 30- } \\
60)\end{array}$ \\
\hline Seoul & 7.71 & 19.38 & 51.98 & 20.63 & 0.31 & 8.29 & 12.94 & 3.33 & 15.37 & 29.42 & 4.55 \\
\hline New York & 5.22 & 12.99 & 54.85 & 20.55 & 6.39 & 32.95 & 9.40 & 10.22 & 8.68 & 2.89 & 11.59 \\
\hline Toronto & 5.20 & 14.26 & 56.50 & 19.56 & 4.47 & 25.53 & 16.41 & 9.22 & 13.07 & 5.37 & 6.92 \\
\hline London & 7.63 & 22.25 & 49.95 & 18.76 & 1.42 & 20.45 & 18.80 & 11.98 & 11.05 & 3.51 & 17.57 \\
\hline Paris & 6.77 & 19.38 & 51.15 & 19.06 & 3.65 & 14.88 & 26.61 & 11.93 & 3.26 & 2.65 & 12.07 \\
\hline Berlin & 9.08 & 21.96 & 57.66 & 10.03 & 1.27 & 5.14 & 37.50 & 18.35 & 11.39 & 1.92 & 6.31 \\
\hline Milan & 4.34 & 23.41 & 65.19 & 6.56 & 0.50 & 8.51 & 29.50 & 3.47 & 3.86 & 13.86 & 17.14 \\
\hline Tokyo & 3.94 & 19.29 & 59.29 & 16.77 & 0.71 & 9.30 & 14.20 & 11.50 & 10.30 & 29.90 & 3.66 \\
\hline Beijing & 10.99 & 22.98 & 62.60 & 2.52 & 0.91 & 11.51 & 8.35 & 16.70 & 6.42 & 3.56 & 21.84 \\
\hline Stockholm & 5.34 & 11.98 & 46.32 & 32.02 & 4.33 & 22.73 & 29.39 & 14.15 & 4.55 & 0.20 & 6.12 \\
\hline $\begin{array}{l}\text { Entire } \\
\text { sample }\end{array}$ & 6.61 & 18.79 & 55.61 & 16.61 & 2.38 & 15.86 & 20.36 & 11.07 & 8.79 & 9.39 & 10.80 \\
\hline
\end{tabular}

Source: our elaboration from GMFS survey (2006)

\footnotetext{
${ }^{6}$ We are also dubious about the significance of the item "unemployed" in the list of occupation, since the alternative item "retired" was absent. In particular, the unemployment rate in Milan is much higher than the official unemployment rate for the province of Milan in 2006 (3.9\%). This can be partially explained by the more generous retirement clauses of the Italian system: in facts, when we restrict the age interval to 30-50 it declines to $10.4 \%$ (the sample average also declining to 7.51 ).
} 
It is therefore impossible to compare direct answers to questions about happiness (or even pride of living in a given city), because it may be distorted by cultural biases in perceptions. However we can reduce the problem, by using individual information as controls. As long as richer and/or healthier people are typically happier, by netting out the effect of individual (self-assessed) income position and health status we reduce the differences across cities, generated by these correlations. In addition, by introducing a city fixed effect, which takes into account any other difference in unobservables among cities, we are left with a "pure" model of association between happiness and quality of city life, irrespective of individual and/or local differences.

Having said all that, our aim is twofold. On one side we provide operational measures of the "quality of city life" obtained by individual responses in the questionnaire. On the other hand, we analyse the correlation between these measures and subjective well-being, controlling for standard covariates. As by-product of the second analysis, we show that individual city fixed effects may have some interpretation, and speculate about them.

\subsection{Measuring the quality of life}

The survey is organised in eight sections, each devoted to a specific aspect of the quality of urban life:

1. Economy (job opportunities, cost of living)

2. Culture and Education (cultural opportunities, tourism, educational system)

3. Welfare (childcare, support to elderly and disabled people, health system, safety net for the poor)

4. Safety (feeling protected, free to circulate without danger)

5. Environment (air and water pollution)

6. Living conditions (transports, availability of shops, parks)

7. City Administration (information, response to citizens, transparency)

8. Community Life (meeting with friends and neighbours, volunteering and social activities)

Each aspect includes two to four statements, which the respondent was asked to express his/her agreement/disagreement about. $^{8}$

We consider these eight aspects as the main descriptors of the quality of urban life. In order to reduce the dimensionality of the problem, we summarise the original 21 items into eight factors extracted by applying principal component analysis. Each factor corresponds to one section of the questionnaire. ${ }^{9}$ Each extracted factor accounts for more than half of the original variability of constitutive items, and therefore can be considered a good summary measure of the corresponding dimensions (see table 3). In

\footnotetext{
7 There is a further caveat. The interviewees were not asked to express their opinions in relative terms (for example by ranking their perceived quality of life in different cities, or by making comparisons "Are you proud of residing in Milan rather than in London?", which would require additional controls about having actually lived in both cities), but just in absolute terms ("Are you proud of residing in Milan?"). In this way, the expressed judgments do not allow a cardinal interpretation, but just an ordinal one.

${ }^{8}$ We did not participate to the design of the survey, and therefore we could not contribute to the inclusion or exclusion of specific item. In our opinion some questions are expressed in ambiguous terms (for example in the case of pollution mixing behaviours and opinions), some are vague (There are many things in my city that I can proudly introduce to visitors) and some other too specific (It is easy to get information about my city via internet). Some aspects are not investigated at all (consumption or income inequalities, territorial segregation, social tensions associated to migrants or racism, political participation, to quote some of them). However, we maintain the impression that most of the aspects perceived by citizenship are more or less precisely included in this survey.

${ }^{9}$ If we abstract from the original grouping of the items into predefined sections, and we apply principal component analysis to the 21 original items, we obtain four factors. After rotation, the first factor correlates to the items of the third and seventh sections (welfare+administration), the second corresponds to the second and sixth sections (culture+living condition), the third to the first and eighth sections (economy+community life) and the fourth to the fourth and fifth sections (safety+environment). For this reason we feel justified in using the original eight sections and the corresponding factors derived from them.
} 
order to obtain additional information about what citizens are typically concerned with, table 4 reports the city averages for each factor extracted. ${ }^{10}$

The first aspect (ECONOMY) includes two original variables (jobs and prices) that exhibit low correlation among them, but nevertheless attain a positive correlation with this factor. Thus high values indicate high job opportunities and high prices. Therefore it is unsurprising to see that this aspect is strongly underlined by Londoners. The second factor (CULTURE) is mostly correlated with cultural opportunities and pride of being able to show at tourists, while exhibiting lower association with the local educational system. It reaches the highest values in Stockholm and Paris samples. The third factor (WELFARE) mixes various aspects of welfare policies (health, assistance, education and counselling), all being positively correlated among them and with the extracted factor. Contrary to our expectation, this aspect is mostly highlighted in Paris and, to a lesser extent, in London samples, while it is lowest in Seoul data. The fourth factor (SAFETY) is associated with feeling safe and protected when walking in the streets. The highest values are recorded in Stockholm and London samples, while the disagreement is maximum among Milan citizens.

The fifth factor (POLLUTION) reverses the algebraic signs in factor loading, a high value indicating lack of confidence in public water as well as high levels of air pollution. The highest values are recorded in Milan and Seoul samples, while the lowest is found in Stockholm sample. The sixth factor (LIVING) mixes the quality of public transports with the existence of a local community, even if shops alone do not always make a relationship; we could condense this factor as "easy and pleasant to wander around". It is highest in Berlin and Stockholm samples, and again lowest in Seoul one. The seventh factor (ADMINISTRATION) is mostly driven by the perception of transparency and vicinity to citizens, while access to internet for administration is less associated to this factor. Once again this factor is highest in Paris and Stockholm sample. Eventually the eighth factor (COMMUNITY) capture the existence of high degree of social activity. Surprisingly, it is highest in Berlin and Milan samples, while lowest in Eastern cities (Tokyo and Seoul in particular).

The average opinions reported in table 4 by citizens of different cities cannot be directly compared, since we do not control for sample compositions or for differences on unobservables. However when we simply look at city ranks according to each indicator, the data convey us some known impression: Stockholm comes out as the most preferable city according to the opinions of its citizens with respect to quality of city life (average rank 2.8); Paris, Berlin and London follow closely (their respective average ranks are 3.6, 3.9 and 4.0). At the other extreme of the distribution, Seoul ranks lowest (average rank 9.5), followed by Beijing (average rank 7.0) and Tokyo (average rank (6.6). Among western cities, Milan and Toronto exhibit perceived levels of life quality which are closer to Eastern Asian cities (respectively 7.0 and 6.0 average ranks). It is also interesting to notice that in some cases the opinions of the citizens are more homogeneous than in others. This may reflect cultural attitudes (for example reluctance to express strong statements, as likely occurring in Seoul or Beijing) but possibly also real contradictions, as in the case of Milan. According to Milan inhabitants, quality of city life is low in terms of welfare provision, public services, safety and pollution, but they rank their city high with respect to the economy and to the community life. This may reflect the pride of Milaneses being the economic and moral capital of the country (recently the city has been made seat of the national authority for NGOs), even when we notice that the city ranks quite low on the quality of local services as well as on cultural ground.

In each city the inhabitants stress some aspects more than others, as suggested by the bolded values in table $4 .{ }^{11}$ Stockholm and New York inhabitants express their appreciation for the cultural opportunities

\footnotetext{
10 Remember that each factor extracted by original variable is standardised by construction (i.e. zero mean and unitary standard deviation). Therefore a positive number in table 4 indicates values above the "world" average; conversely negative values correspond to cases below the average. An almost unitary coefficient indicates one standard deviation detachment from the "world" mean.
} 
of their cities, Beijing and Paris for the quality of welfare provisions, Milan and Toronto for the level of community life, while London and Seoul samples highlight the economic opportunities offered by their cities. Eventually Berlin and Tokyo inhabitants emphasise the quality of living conditions and lack of pollution respectively.

Table 3 - Description of QUALITY OF URBAN LIFE indicators

\begin{tabular}{|c|c|}
\hline \multicolumn{2}{|l|}{ Factor 1 = Economy - proportion of variance explained: 0.5543} \\
\hline 1-1. There are plenty of job opportunities in my city. & load.factor: 0.7445 \\
\hline 1-2. The price of living in my city is high. & load.factor: 0.7445 \\
\hline \multicolumn{2}{|l|}{ Factor 2 = Culture - proportion of variance explained: 0.5364} \\
\hline 2-1. My city allows easy access to culture and leisure facilities. & load.factor: 0.8096 \\
\hline 2-2. There are many things in my city that I can proudly introduce to visitors. & load.factor: 0.8140 \\
\hline 2-3. I am satisfied with the quality of education in my city. & load.factor: 0.5395 \\
\hline \multicolumn{2}{|l|}{ Factor $3=$ Welfare - proportion of variance explained: 0.5140} \\
\hline 3-1. In times of personal or family crisis, I can turn to the city's public institutions and facilities for help. & load.factor: 0.7162 \\
\hline 3-2. My city is a good place to rear and care for children. & load.factor: 0.6911 \\
\hline 3-3. My city has many facilities for the socially disadvantaged people such as the old, the handicappec & load.factor: 0.7461 \\
\hline 3-4. I am satisfied with the quality of health care in my city. & load.factor: 0.7132 \\
\hline \multicolumn{2}{|l|}{ Factor 4 = Safety - proportion of variance explained: 0.6632} \\
\hline 4-1. I feel safe walking around the city at night. & load.factor: 0.8144 \\
\hline 4-2. I feel safe from the danger of various accidents such as car accidents, fires, and building collapses. & load.factor: 0.8144 \\
\hline \multicolumn{2}{|l|}{ Factor $5=$ Pollution - proportion of variance explained: 0.5127} \\
\hline 5-1. I feel safe when I drink publicly provided water. & load.factor: -0.7160 \\
\hline $5-2$. Air pollution is a serious problem in my city. & load.factor: 0.7160 \\
\hline \multicolumn{2}{|l|}{ Factor $6=$ Living - proportion of variance explained: 0.5235} \\
\hline 6-1. It is convenient to use public transportation e.g., subways, trains, or buses, in my city. & load.factor: 0.6812 \\
\hline $\begin{array}{l}\text { 6-2. There are many places in my neighborhood or within walking distance from the place that I live, where I can sit and } \\
\text { relax, or talk peacefully to neighbors and friends. }\end{array}$ & load.factor: 0.7309 \\
\hline 6-3. I can easily walk to buy groceries at shops in my neighborhood or within walking distance to the place that I live. & load.factor: 0.7564 \\
\hline \multicolumn{2}{|l|}{ Factor $7=$ Administration - proportion of variance explained: 0.5459} \\
\hline 7-1. It is easy to get information about my city via internet. & load.factor: 0.4483 \\
\hline 7-2. The city govemment does a good job addressing citizen concems and requests. & load.factor: 0.8574 \\
\hline 7-3. The city administration is transparent. & load.factor: 0.8376 \\
\hline \multicolumn{2}{|l|}{ Factor 8 = Community-proportion of variance explained: 0.6379} \\
\hline 8-1. I try to have my friends or neighbors come over to my home as frequently as possible. & load.factor: 0.7987 \\
\hline 8-2. There are many opportunities for volunteer activities in my city. & load.factor: 0.7987 \\
\hline
\end{tabular}

Table 4 - Indicators of QUALITY OF CITY LIFE by city

factors extracted from original items (see table 3)

\begin{tabular}{|l|c|c|c|c|c|c|c|c|}
\hline city & economy & culture & welfare & safety & pollution & living & administrat & community \\
\hline Beijing & -0.309 & -0.207 & $\mathbf{0 . 1 4 7}$ & 0.031 & -0.010 & -0.155 & -0.074 & -0.158 \\
\hline Berlin & -0.381 & 0.397 & 0.027 & 0.039 & -0.474 & $\mathbf{0 . 5 0 5}$ & 0.077 & 0.471 \\
\hline London & $\mathbf{0 . 5 8 4}$ & 0.305 & 0.219 & 0.310 & -0.078 & -0.084 & -0.048 & 0.187 \\
\hline Milan & 0.274 & -0.170 & -0.168 & -0.738 & 0.790 & -0.182 & 0.004 & $\mathbf{0 . 3 6 8}$ \\
\hline New York & 0.149 & $\mathbf{0 . 1 6 6}$ & -0.075 & 0.246 & -0.155 & 0.270 & 0.109 & 0.157 \\
\hline Paris & 0.302 & 0.558 & $\mathbf{0 . 6 6 9}$ & -0.025 & 0.054 & 0.231 & 0.201 & 0.349 \\
\hline Seoul & $-\mathbf{0 . 1 3 8}$ & -0.994 & -1.171 & -0.584 & 0.802 & -0.877 & -0.581 & -0.922 \\
\hline Stockholm & 0.364 & $\mathbf{0 . 6 7 9}$ & 0.021 & 0.375 & -0.750 & 0.490 & 0.172 & 0.011 \\
\hline Tokyo & -0.837 & -0.756 & -0.009 & 0.158 & -0.295 & -0.078 & 0.015 & -0.825 \\
\hline Toronto & 0.027 & 0.080 & 0.183 & 0.204 & 0.109 & -0.167 & -0.079 & $\mathbf{0 . 2 5 4}$ \\
\hline
\end{tabular}

Note: bolded values indicate the highest value reported for each city. Values referred to "pollution" are considered with the reverse sign, indicating "lack of pollution"

\footnotetext{
${ }^{11}$ In factor analysis we cannot control for city-specific effects (like education, religion, political representation), which may systematically affect the opinions expressed by the interviewees. However, as long as these distortions affect the opinions over all domains, the comparison of alternative city rankings according to different dimensions is still meaningful.
} 
Table 5 - City ranks according to indicators of QUALITY OF CITY LIFE (see table 4)

\begin{tabular}{|l|c|c|c|c|c|c|c|c||c|c|}
\hline City & economy & culture & welfare & safety & $\begin{array}{c}\text { lack of } \\
\text { pollution }\end{array}$ & Living & administr & community & $\begin{array}{c}\text { average } \\
\text { rank }\end{array}$ & $\begin{array}{c}\text { st.dev } \\
\text { rank }\end{array}$ \\
\hline Beijing & 8 & 8 & 4 & 7 & 6 & 7 & 8 & 8 & 7.0 & 1.41 \\
\hline Berlin & 9 & 3 & 5 & 6 & 2 & 1 & 4 & 1 & 3.9 & 2.75 \\
\hline London & 1 & 4 & 2 & 2 & 5 & 6 & 7 & 5 & $\mathbf{4 . 0}$ & 2.14 \\
\hline Milan & 4 & 7 & 9 & 10 & 9 & 9 & 6 & 2 & $\mathbf{7 . 0}$ & 2.83 \\
\hline New York & 5 & 5 & 8 & 3 & 4 & 3 & 3 & 6 & 4.6 & 1.77 \\
\hline Paris & 3 & 2 & 1 & 8 & 7 & 4 & 1 & 3 & 3.6 & 2.62 \\
\hline Seoul & 7 & 10 & 10 & 9 & 10 & 10 & 10 & 10 & 9.5 & 1.07 \\
\hline Stockholm & 2 & 1 & 6 & 1 & 1 & 2 & 2 & 7 & $\mathbf{2 . 8}$ & 2.38 \\
\hline Tokyo & 10 & 9 & 7 & 5 & 3 & 5 & 5 & 9 & $\mathbf{6 . 6}$ & 2.50 \\
\hline Toronto & 6 & 6 & 3 & 4 & 8 & 8 & 9 & 4 & $\mathbf{6 . 0}$ & 2.20 \\
\hline
\end{tabular}

We notice that the general image of the cities emerging from this survey corresponds to the common reputation cities have in the public opinion, except in two cases. Toronto is held being a city of good quality, nevertheless she ranks low. One possible explanation relates to her inhabitants being accustomed to high quality standards, and therefore being more critical about what they have. On the other side Beijing is an fast changing city, which reflects in the perception of her inhabitants. We believe that a new survey, conducted after the conclusion of the recent and extraordinary Olympic Games of 2008, would have given very different results, both in terms of pride and appreciation of the qualities of the city.

\subsection{Quality of life, subjective well-being and pride of living in a city}

If previous indicators are convincing measures of different dimensions of the quality of urban life, we can now investigate the existing correlation between subjective well-being and these dimensions. Subjective well-being is measured by the answer to the question "How happy are you now ?". ${ }^{2}$ The survey also contains a question about the pride of living in a city, which may help to shed some light on the relationship between quality of life and well-being: "How proud are you of residing in the city ?". In facts, consistency of judgments would exclude negative judgements on different aspects of city life associated with citizens' pride of living in the same city. More controversial is the relationship between pride and happiness, since people could be proud and unhappy, or conversely they could be happy without being pleased of living in a city. However the unconditional correlation between these two opinions is positive and significant (0.38).

In table 6 we report the correlation between happiness and city pride with the different indicators of quality of city life. ${ }^{13}$ They describe the association between happiness (or pride) and the quality of life proxy measures, other aspects (gender, age, education, occupation, income, health, marital status and religion) made identical across cities. In addition, we also include city fixed effects, in order to account for other cultural dimensions which could systematically distort the opinions expressed by different samples.

The individual controls are coherent with what already found in the literature: generally speaking women are happier (and prouder) than men, while marital single are dissatisfied. Happiness is

\footnotetext{
12 In order to analyse the answers to the questionnaire, we have recoded each item by assigning -2 to "not happy at all", -1 to "not very happy", 0 to "neither happy nor unhappy", "don't know" and "refusal", +1 to "somewhat happy" and +2 to "very happy". Results are unaffected when recoding to missing "don't know" and "refusal", but sample sizes are significantly reduced in some areas. Similarly, the answer to the questions about pride of living in a city have been recoded in order to assign positive values to affirmative assessments, and negative values to disapproving ones, with zero values to neutral judgments.

13 The numbers reported in table 6 corresponds to the beta coefficients associated to the estimated parameters with ordinary least square methods. The full version of the least square estimates are reported in column 3 of tables A.1 (happiness) and A.2 (pride) of Appendix 1, which also show the estimated coefficients under an alternative statistical model (ordered probit).
} 
increasing in income position and health status, while non-linearly related with education. On the contrary, pride is unrelated to educational attainment or high-income position, whereas has a positive correlation with health condition. In both cases, happiness and pride are reduced for manual workers. It is interesting to notice that protestant religion is positively and significantly associated to happiness.

It is interesting to notice that happiness and pride are similarly related to the quality of urban life, as described by our factors. The expressed opinions on ECONOMY and POLLUTION seem irrelevant with respect to both happiness and pride. Happiness is mostly affected by COMMUNITY LIFE (which has the highest impact) followed by LIVING CONDITIONS and, slightly less pronounced, by WELFARE insurance and CULTURE. On the contrary, pride is strongly associated to cultural offer ${ }^{14}$, and at a lower degree with WELFARE and LIVING CONDITIONS. It is also worth stressing that SAFETY affect pride but not happiness.

It seems that subjective well-being is mostly associated with a good state of human relationships. As already noticed by Frey and Stutzer (2002), experiencing social and/or friendship networks make people happier. According to our results, meeting other people (whether friends or neighbours is equivalent) and/or devoting spare time to volunteer activities makes people feel better. But this also requires a good spatial quality of the city, as suggested by the opinions expressed with respect to living conditions: the availability of public spaces and of vital commercial streets in connection with an efficient transport system seem to represent the best combination that decision makers may offer to increase citizens' well-being. On the contrary, pride of living in a city is associated with partially different factors, mostly with the availability of cultural offers, and at a lower degree with the quality of the local welfare system and the living conditions. It is also interesting to observe that other dimensions (from ECONOMY to SAFETY, from POLLUTION to CITY ADMINISTRATION) are uncorrelated with subjective well-being.

Of course the quality of city space has constantly been a central concern for architects and planners, who have always connected this to the quality of life in cities and therefore to the happiness of people. From the "Garden City" to the "City Beautiful" movement at the beginning of the twentieth century, from the precepts of the Modern Movement to the fierce criticism of it proposed by Jane Jacobs in the sixties (Jacobs 1962), to the theories of the good city form proposed by Kevin Lynch in the '70s (Lynch 1981), up to the entire recent debate about "urban renaissance", there has always been an underlying assumption that happiness is intimately connected to the quality of space. The interesting aspect is that now we have the opportunity to directly test citizens across different metropolitan areas of the world about how much they do value the physical quality of their cities. We show that generally speaking they confirm its importance as a (pre)condition for the development of social life, which in turn is the most important factor connected with personal happiness.

Table 6 - Correlation between happiness, pride and quality of city life - beta OLS coefficient estimates, controlling for standard individual demographics and city fixed effects

\begin{tabular}{l|cc}
\hline & happiness & pride \\
\hline economy & 0.027 & -0.002 \\
culture & $0.066^{* * *}$ & $0.189^{* * *}$ \\
welfare & $0.067^{\star * *}$ & $0.091^{* * *}$ \\
safety & 0.003 & $0.046^{* * *}$ \\
lack of pollution & 0.007 & 0.016 \\
living conditions & $0.074^{* * *}$ & $0.093^{* * *}$ \\
administration & 0.01 & $0.060^{* * *}$ \\
community life & $0.098^{* * *}$ & $0.062^{* * *}$ \\
\hline * significant at 10\%; ${ }^{* *}$ significant at $5 \%{ }^{* * *}$ significant at $1 \%$
\end{tabular}

\footnotetext{
${ }^{14}$ However there may be some association between how the two questions were formulated. The question about pride is "How proud are you of residing in the city?", while one of the questions summarised in the factor CULTURE reads "There are many things in my city that I can proudly introduce to visitors." The unconditional correlation between the two variables is 0.36 .
} 
These results are independent from local specificities, and leave us unable to assess whether living in city A makes people happier than living in city B. The city fixed effect coefficients reported in table A.1 represent the average level of happiness once we control for compositional effects related to income, health or religion, as well as for the opinions expressed with respect to different aspects of quality in urban life. According to them, inhabitants of New York or Toronto would be among the happiest citizens of the world, whereas people living in Milan or Beijing would be among the least happy. On the contrary, these coefficients capture all systematic difference in happiness judgments, which are not related to the distribution of observable individual characteristics and/or individual perceptions of life quality. However, if these unobservable factors affect opinions about both subjective well-being and city pride in similar ways, then there can be something to be learnt by observing and comparing these fixed effect coefficients, which are plotted in figure $1 .^{15}$ It is interesting to notice that there are cities (like New York or Toronto) whose citizens express on average a high level of pride of residing there, irrespective of opinions expressed with respect to quality of city life; the same citizens tend also on average to be enthusiastic with respect to their life satisfaction, but even taking this into account, the difference between the two effects seems dominated by the "pride effect". Milan and Beijing show a similar pattern, even if they start from lower (or even negative) levels of life satisfaction. At the other extreme is the case of Berlin: citizens here are as happy as the average, but they are not at all proud of their city. ${ }^{16}$

Summing up, in the overall sample we have identified some general patterns in the opinions of the citizens interviewed by the GMS survey. First of all, even after controlling for individual characteristics, we found that the subjective well-being is strongly correlated with the opportunity of personal relationships, which are given both by the town physical structure (availability of meeting places, accessibility of local shops, mobility) and by the existing social organisation of life (local meeting opportunities, volunteering). Second, we have shown that subjective well-being and pride of living in a specific city may be uncorrelated, since the latter seem more affected by the cultural opportunities offered by a city, as well as by the good functioning of the local welfare provisions. Third, we have shown that there are some cities (definitively New York, but also Milan and Beijing) whose citizens seem constantly prouder of their cities, irrespective of their conditions (in terms of income, education or health status) or of what are their opinions about the good working of their cities.

Taken at face value, a local politician could learn something from our results. ${ }^{17}$ If $\mathrm{s} /$ he is concerned with the well-being of his/her constituency, s/he should create opportunities for meeting people, in order to intensify personal ties. Similarly, if $s /$ he is concerned with the city pride of the citizenship, $\mathrm{s} /$ he should expand the cultural opportunities and have a look to the working of the welfare system. What our data cannot tell us is whether the electoral behaviour of the citizenship (which is what any politician is mostly concerned with) is more affected by individual perception of well-being or by the pride of living in a specific city. If we knew the answer, we would get a clue in selecting the optimal policies.

\footnotetext{
15 The coefficients and their statistical significance can be traced in columns 3 of tables A.1 - happiness and A.2 - city pride. ${ }^{16}$ Here it would have been interesting to know whether the Berlin interviewees were resident in the formerly Eastern or Western part of the city, or they were just new comers. We suspect that city pride in this case may be strongly influenced by past history events.

${ }^{17}$ It is important to recall that our indicators of quality of life are not obtained from hard measures of actual policies (like spending per capita) but from aggregation of opinions expressed by a sample of the citizens. In addition, we are able to present just simple correlations between subjective well-being (or city pride) and these indicators, without being able to provide causal interpretation of these effects.
} 


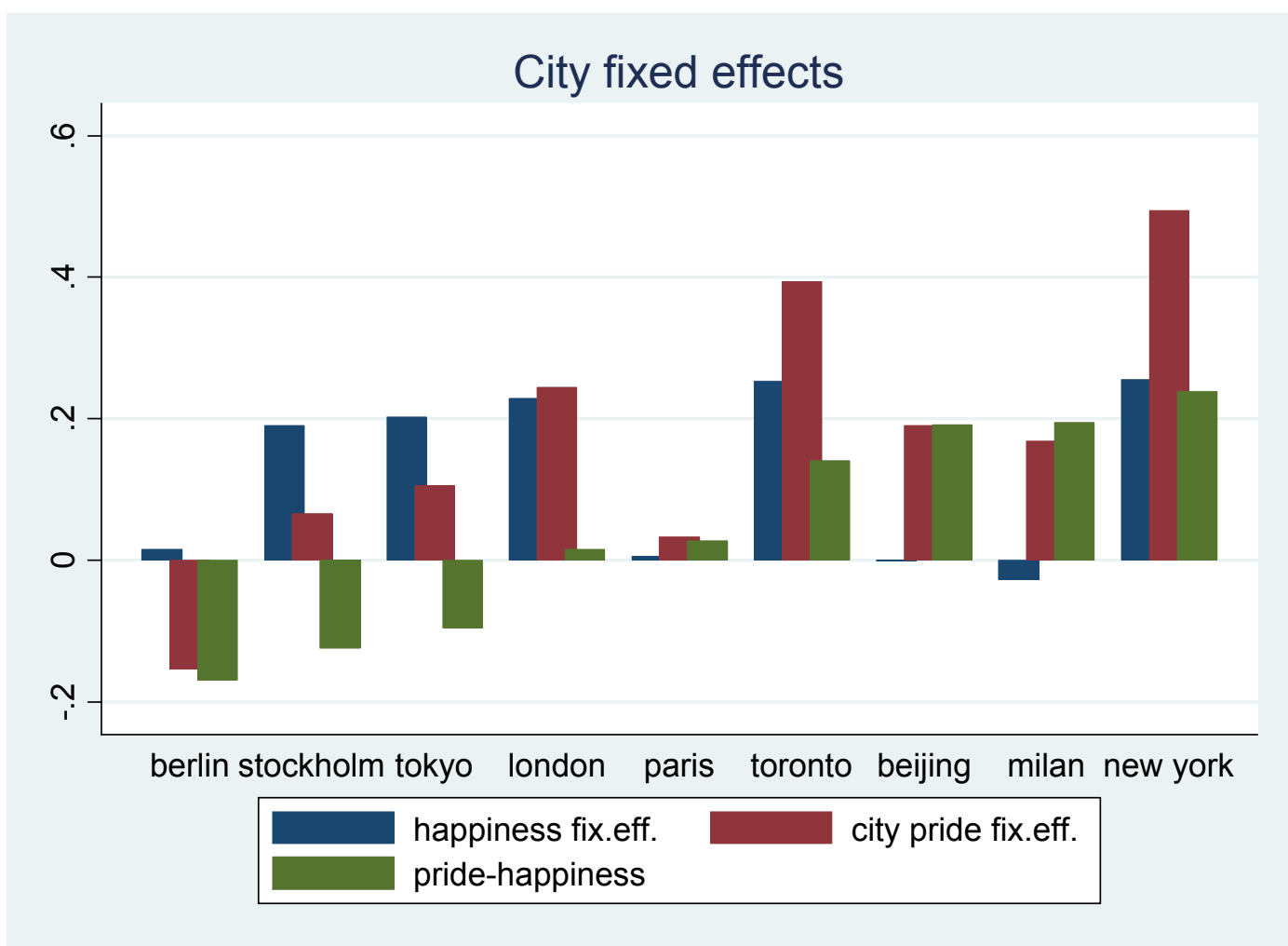

Figure 1 - City fixed effect (Seoul reference case)

\subsection{Local variation in the relationship between quality of life and subjective well-being}

Our statistical models implicitly assume a unique pattern of well-being (or pride) generation across countries. This unique model may fit the data better for some cities than for others (as can be inferred from the statistical significance of the corresponding city fixed effect - see column 3 in tables A.1 and A.2). However a unique worldwide model of generating happiness (or pride) represents a heroic assumption, given cultural diversities across countries. For this reason, in tables 7 and 8 we re-estimate the global model by subsamples, showing the correlations between the quality of life indicators and happiness on one side and city pride on the other by metropolitan areas. Standard individual controls (like gender, age, education, etc) are obviously maintained.

By looking at the associations between subjective well-being and indicators of quality of urban life reported in table 7, we notice that our global model presented in previous subsection (see table 6) is effectively applicable to most city samples. The indicators of LIVING CONDITIONS and COMMUNITY LIFE are positively and significantly correlated with citizens' happiness in eight/seven cases out of ten. More dissimilarities among cities emerge when looking at the other two indicators which are significantly correlated with happiness at global level: the indicators for WELFARE and CULTURE are only significant in five/four cases. There are local specificities in the association between subjective wellbeing and life quality. Some cities exhibits happiness correlation with fewer indicators (Seoul with LIVING conditions, Paris with Welfare and COMMUNITY LIFE, Toronto with CUlTuRE and WeLFARE), while other samples contains more complex models of associations (Berlin being the extreme case where citizens' well-being is associated with all indicators but WELFARE and SAFETY). Despite we searched the potential existence of continental models of happiness correlations, we do not find strong similarities among Asian cities (Seoul, Beijing and Tokyo) or among continental European cities (Milan, Stockholm, Berlin and Paris) or in the Anglo-Saxon world (London, New York and Toronto). The case of Milan, which will be discussed more extensively in the next section, shows positive association of happiness with WELFARE, LIVING CONDITIONS and CITY ADMINISTRATION, but surprisingly not with COMMUNITY LIFE (despite the high value recorded by the city on this indicator). 
Table 7 - Happiness and quality of life

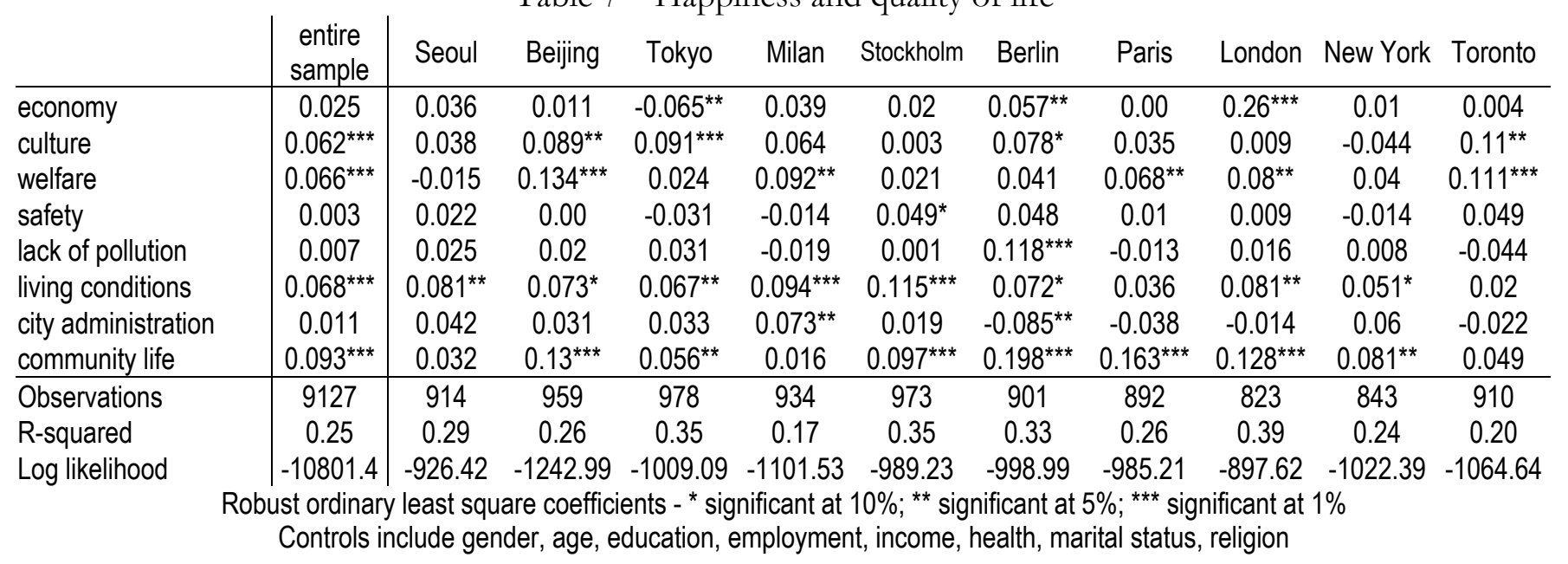

When we consider the local models of association between city pride and quality of urban life, the global model finds support at local level: CULTURE is significant in eight cases out of ten, while LIVING CONDITIONS and WELFARE in seven cases out of ten. Also the quality of CITY ADMINISTRATION reinforces the pride of resident citizens (seven cases out of ten), while ECONOMY (one significant case), SAFETY and LACK OF POLLUTION (four significant cases) seems less relevant for their correlation with pride.

Table 8 - Pride and quality of life

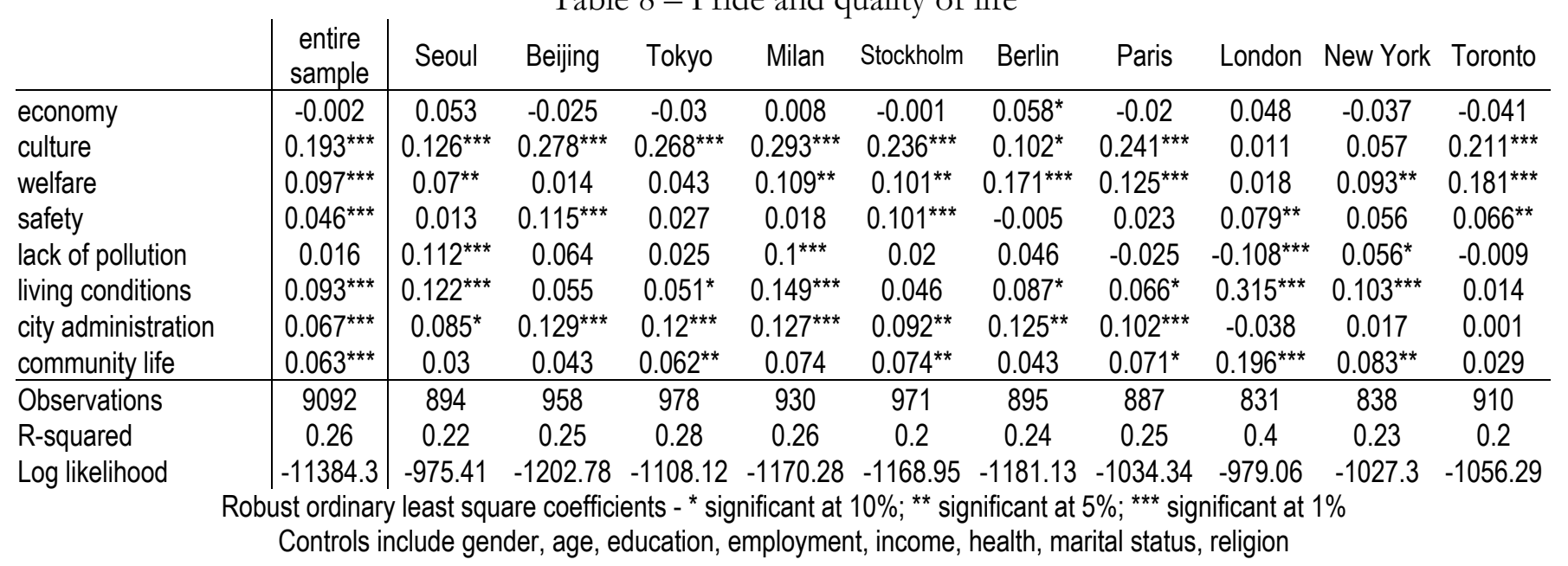

With respect to our focus on the city of Milan, we take the estimated Beta coefficients from previous tables 7 and 8 and plot them in a comparable way in figure 2. We notice that what makes most of the difference between happiness and pride in Milan is the cultural offer. However, the two statistical models reveal similarities: WELFARE, LIVING CONDITIONS and CITY ADMINISTRATION raises both subjective well-being and city pride. On the other hand, as we have already shown in the previous subsection, the overall level of the former is lower than the level of the latter. Milan residents are quite proud of their city despite they do not achieve high level of well-being. This attitude seems induced by perception of local cultural opportunities (which is common to most Italian cities) as well as by opportunities to meet other people. However it is worth noticing that personal ties and volunteering show no correlation with both happiness and city pride. Milaneses seem to deceive themselves: they are proud of living in a city offering a lot of opportunities (in terms of culture and meeting prospects), without being able of taking advantage of them (because both indicators of CULTURE and COMMUNITY LIFE do not correlate with their well-being). The interpretation of these contradictory perceptions is the goal of the next section. 


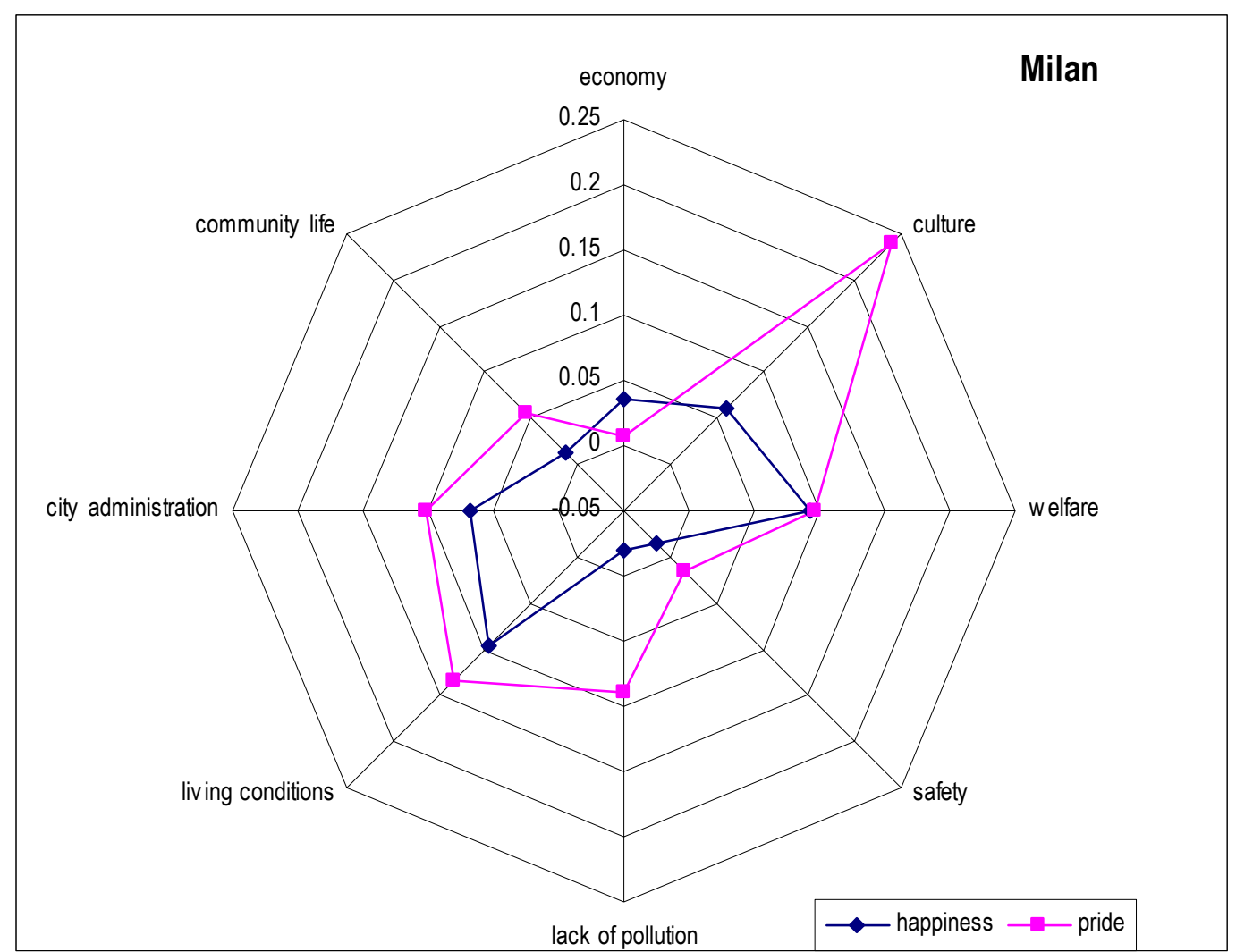

Figure 2 - Estimated impact of the quality of life onto happiness and city pride - Milan Note: beta coefficients corresponding to estimates reported in tables 7 and 8

\section{HAPPINESS AND CITY PRIDE: THE CASE OF MILAN}

Milan inhabitants are proud of residing in their city, despite the fact that most of the potential indicators of the quality of urban life do not affect their judgment (nor their subjective well-being). We suspect that most of their perceptions is framed in a general context of successful adaptation to productive changes, without being aware of the costs of this change. Let us briefly review these issues.

Milan is the most dynamic metropolitan city in Italy. During the 70's it experienced a deep crisis when it was feared that the progressive decline of the industrial manufacturing sector would have implied a decline of the city itself. However, in a period when the knowledge economy is driving the economic growth, Milan has been able to overcome that crisis (Foot 2001). The city has always been considered as a crucial pole of the most developed urban Europe, from the Blue Banana (Figure 3) proposed by the French Datar in the 1980s to the more recent Espon Pentagon (Figure 4). 


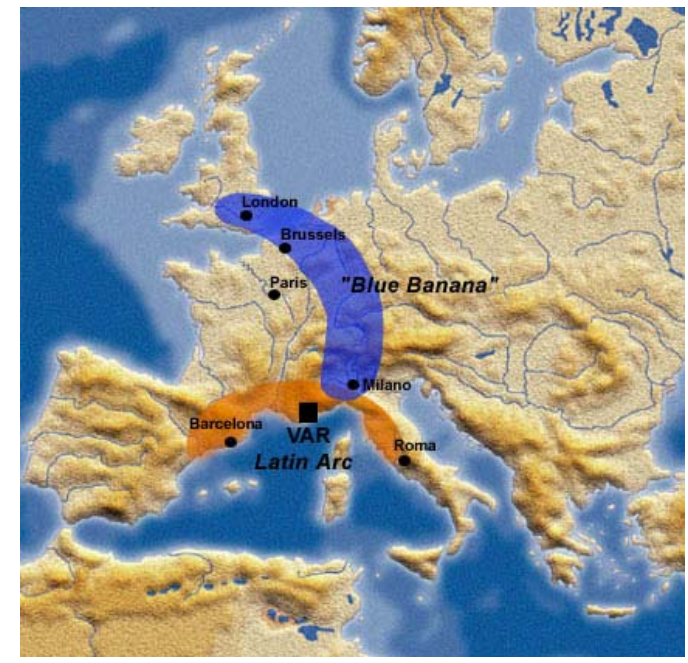

Figure 3 - The Blue Banana

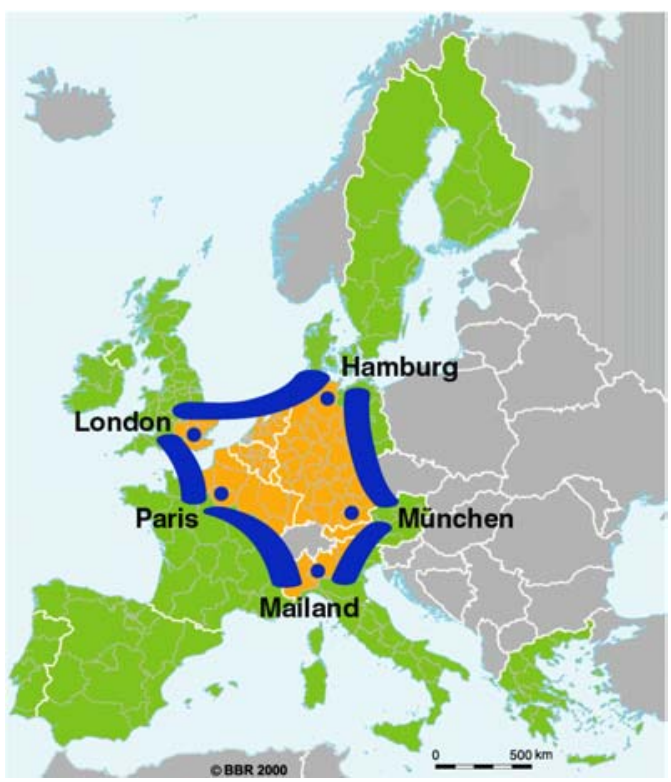

Figure 4 - The Espon Pentagon

We can look at some basic data in order to understand the deepness of the change. Milan is one of the Italian richest cities: the GDP per capita in 2005 was 35.776 euros, while the Italian mean was 24.152 euros. It accounts for $9.7 \%$ of the national GDP, while the population accounts for just $6.2 \%$. Despite being the heart of the national economic life, in the last two decades (between 1991 and 2001, both Census years) the Province of Milan ${ }^{18}$ has lost one third of the jobs in the manufacturing sector, while obtaining a parallel increase of $42.9 \%$ in the number of jobs in the service sector, the overall increase in jobs scoring at $5.9 \%$ (see Table 9). But the most important change has been the increase in the number of firms, which has overpassed the growth rate of jobs ( $+59.4 \%$ over the same time span). The obvious consequence has been a dramatic decline in firm size in the industrial sector, while exhibiting no trend in the service sector. This means that Milan has overcome the economic crisis through a structural change and a fragmentation process. A structural change from manufacturer to service sector and a fragmentation of the number of enterprises that had a direct impact not only in the economic environment, but also upon the number of actors who take decisions.

\begin{tabular}{|c|c|c|c|c|}
\hline & $\begin{array}{c}\text { census } \\
\text { year } 1971\end{array}$ & $\begin{array}{c}\text { census } \\
\text { year } 1981\end{array}$ & $\begin{array}{c}\text { census } \\
\text { year } 1991\end{array}$ & $\begin{array}{c}\text { census } \\
\text { year } 2001\end{array}$ \\
\hline \multicolumn{5}{|c|}{ Employment } \\
\hline Industry & 895773 & 825735 & 697723 & 555068 \\
\hline among which building sector & 73211 & 69376 & 91135 & 93531 \\
\hline Services & 496493 & 862641 & 1020130 & 1233362 \\
\hline \multicolumn{5}{|c|}{ Workplaces } \\
\hline Industry & 56240 & 70436 & 73840 & 81466 \\
\hline among which building sector & 9110 & 16145 & 23221 & 33745 \\
\hline Services & 123710 & 163490 & 197335 & 291477 \\
\hline \multicolumn{5}{|c|}{ Firm size (employment per workplace) } \\
\hline Industry & 15.93 & 11.72 & 9.45 & 6.81 \\
\hline among which building sector & 8.04 & 4.30 & 3.92 & 2.77 \\
\hline Services & 4.01 & 5.28 & 5.17 & 4.23 \\
\hline
\end{tabular}

Source: Italian National Statistical Office (ISTAT) - various Census

\footnotetext{
18 The local government has three administrative levels in Italy: the city (administered by a municipality), the province (corresponding approximately to a county) and the region (in the case of Milan, the regional government of Lombardy administers eleven provinces, including the province of Milan).
} 
Table 10 - Employment condition - City of Milan - 1991-2001

\begin{tabular}{|c|c|c|c|c|c|c|}
\hline & & cens & year 2001 & & & \\
\hline & & Men & & & women & \\
\hline & $15-29$ & $30-49$ & 50 and over & $15-29$ & $30-49$ & 50 and over \\
\hline employed & 51188 & 168615 & 80180 & 45903 & 141442 & 49004 \\
\hline unemployed & 10044 & 9416 & 4686 & 8229 & 9084 & 2760 \\
\hline students & 34886 & 1453 & 8 & 35861 & 1793 & 12 \\
\hline housewife & 58 & 197 & 857 & 4113 & 29842 & 119430 \\
\hline pensioners & 124 & 741 & 135211 & 231 & 2532 & 133714 \\
\hline others & 3641 & 5766 & 9587 & 1951 & 3947 & 14858 \\
\hline total & 99941 & 186188 & 230529 & 96288 & 188640 & 319778 \\
\hline participation rate & $61.27 \%$ & $95.62 \%$ & $36.81 \%$ & $56.22 \%$ & $79.80 \%$ & $16.19 \%$ \\
\hline employment rate & $51.22 \%$ & $90.56 \%$ & $34.78 \%$ & $47.67 \%$ & $74.98 \%$ & $15.32 \%$ \\
\hline unemployment rate & $16.40 \%$ & $5.29 \%$ & $5.52 \%$ & $15.20 \%$ & $6.03 \%$ & $5.33 \%$ \\
\hline
\end{tabular}

\begin{tabular}{|c|c|c|c|c|c|c|}
\hline & & cens & year 1991 & & & \\
\hline & & Men & & & women & \\
\hline & $15-29$ & $30-49$ & 50 and over & $15-29$ & $30-49$ & 50 and over \\
\hline employed & 74766 & 161995 & 94104 & 63567 & 119830 & 39658 \\
\hline unemployed & 20112 & 1938 & 3002 & 18228 & 6742 & 1093 \\
\hline students & 54244 & 806 & 0 & 53360 & 816 & 0 \\
\hline housewife & 0 & 0 & 0 & 9679 & 54407 & 163276 \\
\hline pensioners & 1427 & 2356 & 121286 & 991 & 5215 & 101867 \\
\hline others & 7352 & 4064 & 13460 & 2237 & 3378 & 15828 \\
\hline total & 157901 & 177954 & 231852 & 148062 & 190388 & 321722 \\
\hline participation rate & $60.09 \%$ & $92.12 \%$ & $41.88 \%$ & $55.24 \%$ & $66.48 \%$ & $12.67 \%$ \\
\hline employment rate & $47.35 \%$ & $91.03 \%$ & $40.59 \%$ & $42.93 \%$ & $62.94 \%$ & $12.33 \%$ \\
\hline unemployment rate & $21.20 \%$ & $1.18 \%$ & $3.09 \%$ & $22.28 \%$ & $5.33 \%$ & $2.68 \%$ \\
\hline
\end{tabular}

The availability of jobs is clearly recognisable, especially when we look at social conditions of the population (see table 10). The employment rate for men in the central age is above $90 \%$, while the corresponding rate for females has grown by 15 percentage points in one decade. If we exclude the juvenile situation, the unemployment rate is close to a frictional one.

Another deep process of change has interested the population structure and its distribution across neighbouring municipalities (see table 11 and figure 5). The city of Milan has lost 1/3 of its population in the last 30 years (approximately 480.000 inhabitants), just like other situations of "shrinking cities", but this did not occur as result of the economic crisis as it took place in the "70s and nowadays in other places (like in East Europe). On the contrary, until the end of the " 80 s the population has moved to the outer part of the Province, which in fact raised during this period to the peak of nearly 4 millions inhabitants and later on towards the bordering provinces around Milan. The fall in the resident population of the inner city has been cushioned by the growth in the percentage of foreign people who have come to account for $10 \%$ of the population, amounting to 132.676 inhabitants in 2001 according to official statistics (which do not include a vast illegal immigration). Without immigration, Milan would have been even more depopulated.

The causes leading to this process of strong decentralisation are well known: on the one hand the strong pressure on urban housing markets, producing a constant rise of urban accommodation costs; on the other hand, the continued expansion of private motor transport, which made it relatively easy to reach more and more distant places. This process has been amplified by the change in the pattern of population distribution, implying a fragmentation of actors: vis-à-vis the constant decline of the population, in the same period we observe a continuous increase in the number of families yielding a corresponding decline in family size (see Table 12). If we add the fall in the birth rate, at the end of the period the $58 \%$ of families in the province consisted of one or two components. As for the number of enterprises we see here a proliferation of decision takers. 
Table 11 - Resident population - City of Milan, its province and bordering provinces - 1951-2001

\begin{tabular}{|l|r|r|r|r|r|r|r|}
\hline Provinces & $\begin{array}{c}\text { census } \\
\text { year 1951 }\end{array}$ & $\begin{array}{c}\text { census } \\
\text { year 1961 }\end{array}$ & $\begin{array}{c}\text { Census } \\
\text { year 1971 }\end{array}$ & $\begin{array}{c}\text { census } \\
\text { year 1981 }\end{array}$ & $\begin{array}{c}\text { census } \\
\text { year 1991 }\end{array}$ & $\begin{array}{c}\text { census } \\
\text { year 2001 }\end{array}$ & $\begin{array}{c}\text { variation } \% \\
1981-2001\end{array}$ \\
\hline City of Milan & 1274154 & 1582421 & 1732000 & 1604773 & 1369231 & 1256211 & $-21.7 \%$ \\
\hline Province of Milan & 2324717 & 2983903 & 3727841 & 3839006 & 3738685 & 3707210 & $-3.4 \%$ \\
\hline \multicolumn{7}{|c|}{ bordering provinces } \\
\hline Novara (west) & 274421 & 303481 & 327901 & 337271 & 334614 & 343040 & $1.7 \%$ \\
\hline Varese (north-west) & 477055 & 581528 & 725823 & 788057 & 797039 & 812477 & $3.1 \%$ \\
\hline Como (north) & 361667 & 405975 & 476209 & 511425 & 522147 & 537500 & $5.1 \%$ \\
\hline Lecco (north-east) & 216046 & 233069 & 265359 & 286636 & 295948 & 311452 & $8.7 \%$ \\
\hline Bergamo (east) & 681417 & 727758 & 807914 & 874035 & 909692 & 973129 & $11.3 \%$ \\
\hline Pavia (south) & 506511 & 518193 & 526389 & 512895 & 490898 & 493753 & $-3.7 \%$ \\
\hline Lodi (south-east) & 180436 & 172912 & 175844 & 179102 & 184025 & 197672 & $10.4 \%$ \\
\hline Piacenza (south-east) & 299138 & 291059 & 284881 & 278424 & 267633 & 263872 & $-5.2 \%$ \\
\hline
\end{tabular}

Figure 5 - Population dynamics

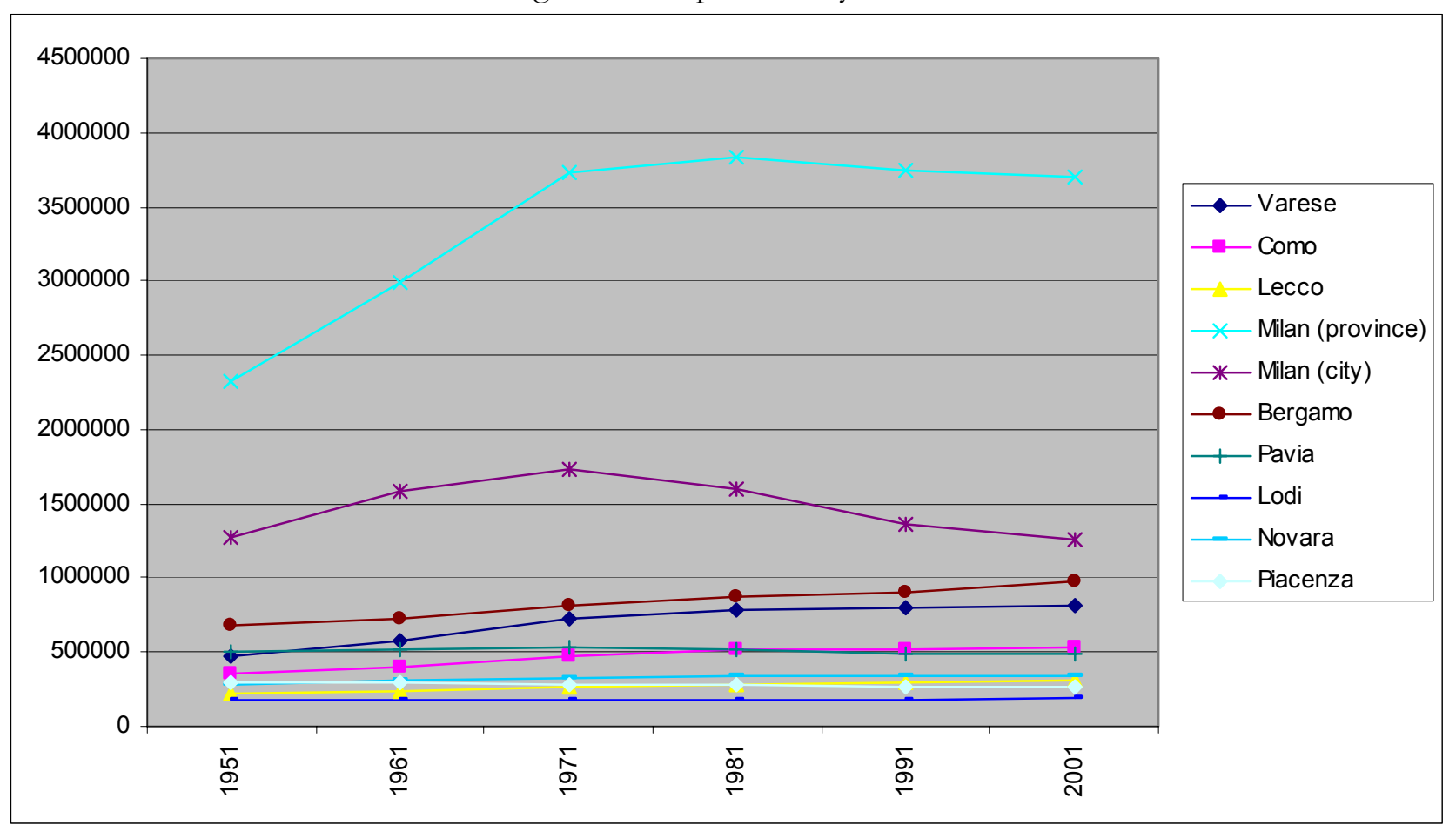

Table 12 - Family size - City of Milan, its province and bordering provinces - 1971-2001

\begin{tabular}{l|cccc} 
Provinces & census & census & census & census \\
& year 1971 & year 1981 & year 1991 & year 2001 \\
\hline City of Milan & 2.76 & 2.53 & 2.32 & 2.11 \\
Province of Milan & 3.01 & 2.79 & 2.61 & 2.38 \\
Novara (west) & 2.83 & 2.65 & 2.54 & 2.39 \\
Varese (north-west) & 3.12 & 2.89 & 2.73 & 2.52 \\
Como (north) & 3.19 & 2.94 & 2.73 & 2.53 \\
Lecco (north-east) & 3.27 & 2.96 & 2.76 & 2.55 \\
Bergamo (east) & 3.41 & 3.03 & 2.8 & 2.57 \\
Pavia (south) & 2.88 & 2.61 & 2.45 & 2.31 \\
Lodi (south-east) & 3.17 & 2.87 & 2.72 & 2.52 \\
Piacenza (south-east) & 3.05 & 2.68 & 2.48 & 2.31 \\
\multicolumn{1}{c}{ Source: Italian National Statistical Office (ISTAT) - various Census }
\end{tabular}

Jointly considered, these transformations had an impact in the physical form of the urban region. Let us observe Milan from two satellite images taken in 1972 and 2001. In the 1972 image (Figure 6), the 
compacted urban structure that developed along some of the spokes, especially towards the North, is still recognisable. A series of centres can be recognised in a crown configuration at a distance of 15-20 $\mathrm{km}$ from Milan. They are second order centres of aggregation that follow a typical crystallerian pattern. The capitals of the bordering provinces are very distinct: Bergamo, Pavia, Piacenza, and also Como, Lecco and Varese to the North.

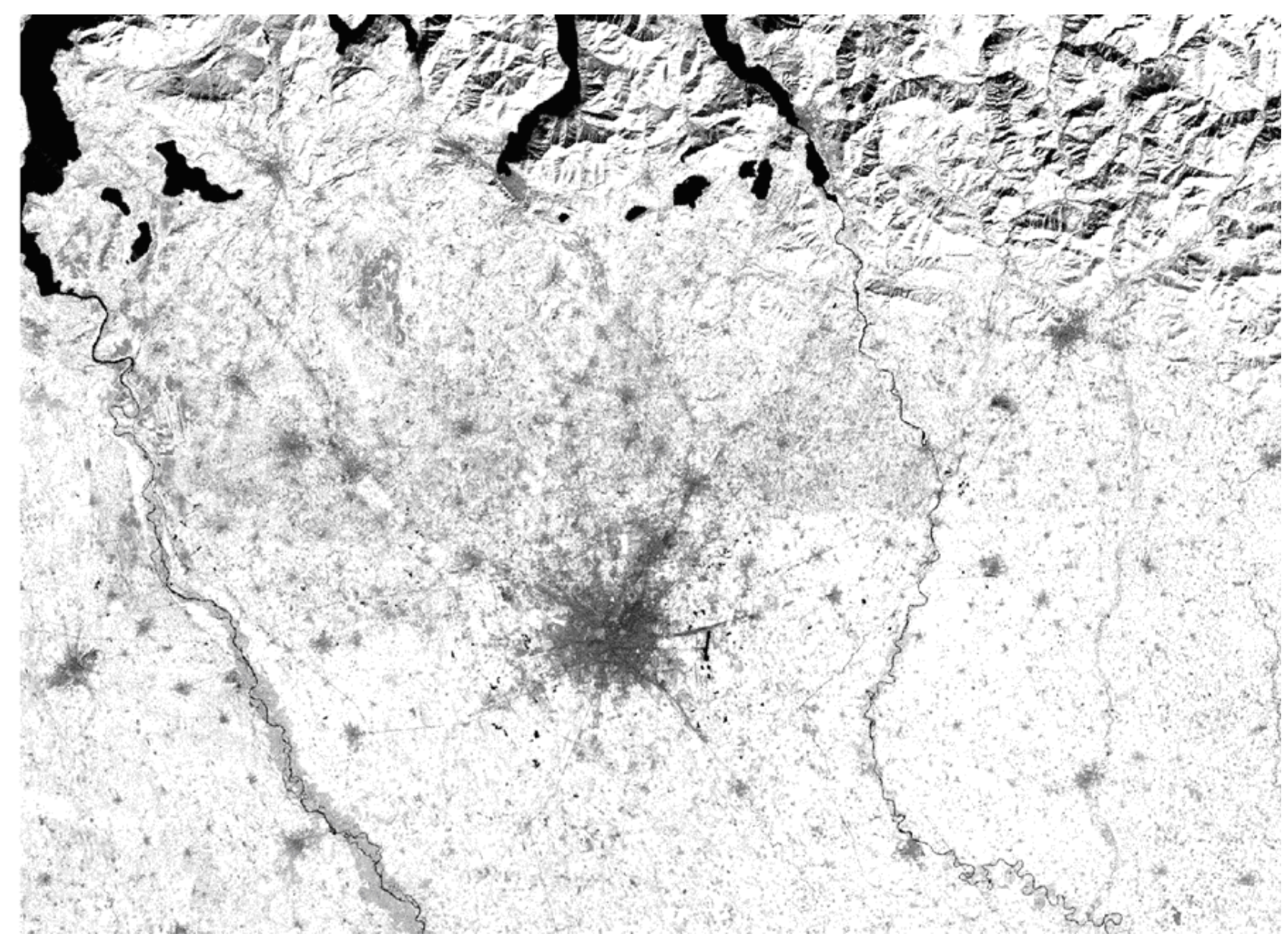

Figure 6 - 1972 satellite image (source Global Land Cover Facility)

The situation in 2001 is very different (Figure 7): a stratum of urbanisation has stretched over the ancient framework. The central area of Milan in the 2001 image has no breaks between it and many of the first and second rings of towns, constituting one single dense urban formation with them. But if we widen our angle of view, we can see two additional interesting phenomena: other dense urban formations appear with their own physiognomy outside Milan, while the bordering provinces have been incorporated in the strongly urbanised and enlarged urban region. 


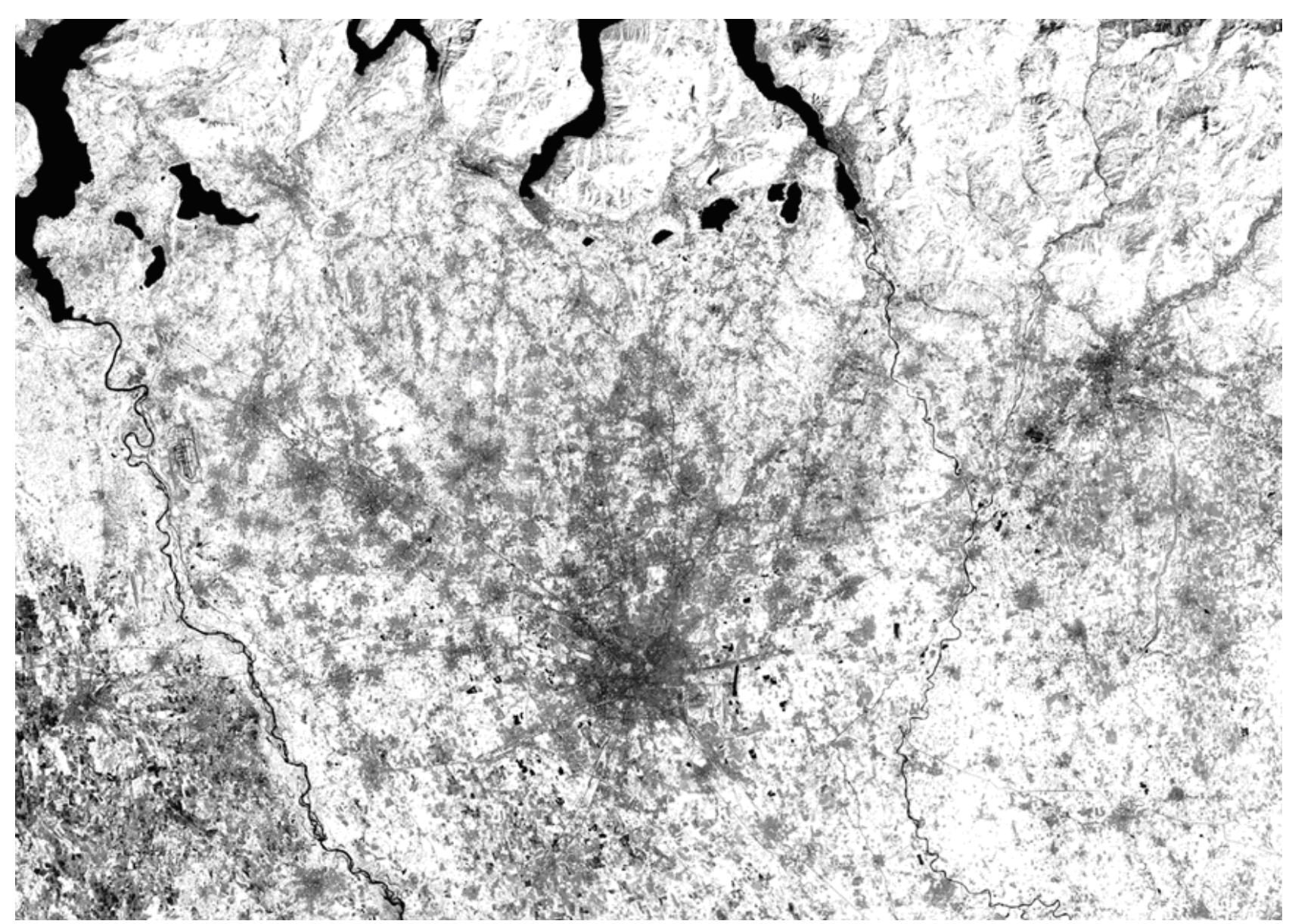

Figure 7 - 2001 satellite image (source Global Land Cover Facility)

To assess the situation of the city we cannot avoid to look at the consequences of this profound change in its structure and pattern. The very substantial loss of population and industrial activities of the core city has been offset by an increase in the population that uses the city either everyday or temporarily.

On this account we register the dramatic consequences of this pattern of development. First of all in terms of land consumption. The Murbandy / Moland (Monitoring Urban Dynamics / Monitoring Land Use Changes) project, carried out by the European Environment Agency (EEA) and the Directorate General Joint Research Centre (DG JRC) of the European Commission (EC), shows the spatial evolution of 25 European urban areas during the last 50 years. (Lavalle et al. 2002). From 1950s to 1990s the loss of agricultural land in the Milan area due to urban sprawl totals $37 \%$ of the entire area, one of the highest score among the main European cities. (tables 13 and figure 8).

Table 13: Loss of agricultural and natural land due to urban sprawl from 1956 to 1998

\begin{tabular}{|l|c|c|c|c|c|}
\hline \multirow{2}{*}{} & $\begin{array}{c}\text { Total area: } \\
\mathrm{Km}^{2}\end{array}$ & \multicolumn{2}{|c|}{$\begin{array}{c}\text { Total urbanised } \\
\text { area: } \mathrm{Km}^{2}\end{array}$} & $\begin{array}{c}\text { Urban sprawl: increase in artificial } \\
\text { area (\%) during the } 40 / 50 \text { years } \\
\text { study period }\end{array}$ & $\begin{array}{c}\text { Loss of agricultural land due } \\
\text { to sprawl vs. total area (\%) } \\
\text { during the 40/50 years study } \\
\text { period }\end{array}$ \\
\cline { 3 - 4 } & $1950 \mathrm{~s}$ & $1990 \mathrm{~s}$ & 103.8 & 37.0 \\
\hline Milan & 325.2 & 114.5 & 233.4 & & 103 \\
\hline
\end{tabular}



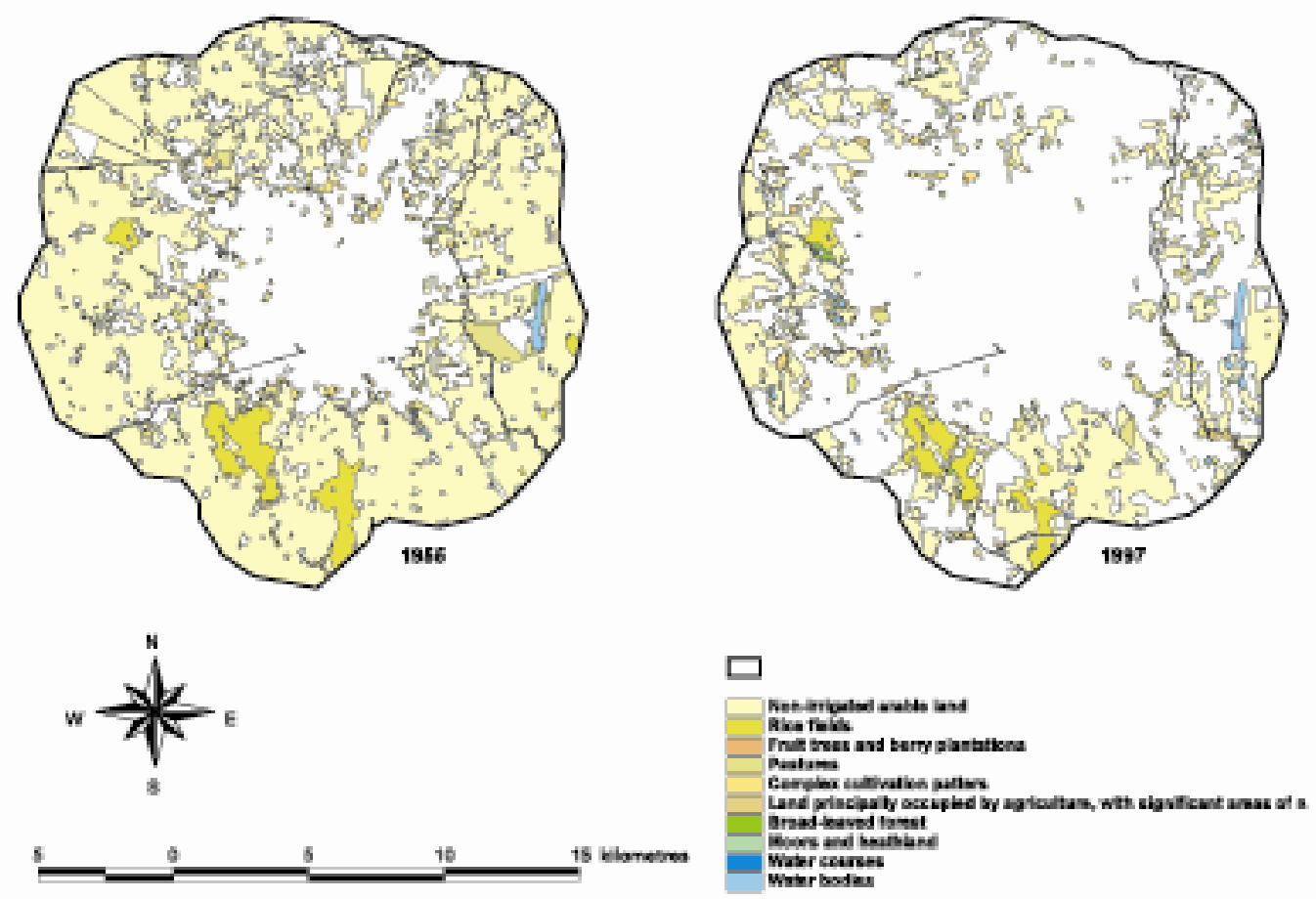

Figure 8. Loss of agricultural and natural land due to urban sprawl from 1956 (left) to 1997 (right) (only natural and agricultural areas are depicted)

More recent data on building permits released by municipalities show that trends in soil loss do not slow down. Indeed from 2000 to 2005, 83.4 millions of cubic metric of new residential and not residential buildings have been realized in the Milan province. ${ }^{19}$

Secondly the air pollution linked to the increase in mobility is nowadays extremely serious: just to cite few data, in 2006 the Milan area recorded 149 days above the maximum threshold of PM10 (polluting micromolecular particles), against a maximum 35 days per year limit established by the European Union. ${ }^{20}$ Similarly we record 829 peaks above the threshold established for the Ozone emissions. ${ }^{21}$ In fact each day between 700.000 and 900.000 vehicles enter the city for different reasons and it is estimated that the daily population almost doubles the number of the resident population.

Thirdly the dynamism of the Milanese economy has brought about a continuous increase in the property market with the correlated problems of finding affordable housing. Recent studies show that there is a need of 55.000 affordable housing today and that in the near future (period 2006-2015) there will be an additional need for 124.000 housing units (Cresme, 2006). The cost of housing has pushed a fraction of the population out of the inner city, the very same population that is now commuting in and out, even from towns and cites quite far away. At the same time, the inhabitants of the inner city commute within the city: one third of them has a travelling time comprised between one quarter and half hour, and another third exceeds half hour each way. From this viewpoint the new city produced perverse effects: the population that moved out in search of more affordable housing replaced the high urban housing costs with the time and cost of travelling. It is a process that has dragged production, commercial and transport activities along with it, which today is dramatically perceived in the forms of traffic congestion, increased consumption of land and high levels of air pollution.

\footnotetext{
${ }^{19}$ Source: Italian National Statistical Office - Istat.

20 Source: Rapporto sulla qualità dell'aria di Milano e Provincia - anno 2005. ArpaLombardia 2006.

${ }^{21}$ Source: RSA Provincia di Milano 2005.
} 
Finally the selective movements of populations in and out the core city have changed the age structure of the city and of the urban region. In 2001 the $22,8 \%$ of the city's population is more than 65 years old, one of the highest in Europe (see Table 14).

\begin{tabular}{l|ccccccccc} 
Table 14 - Age structure - Milan and province - 2001 - Proportion of total population \\
& $0-5$ & $5-14$ & $15-19$ & $20-24$ & $25-34$ & $35-54$ & $55-64$ & $65-74$ & $\begin{array}{c}75 \text { and } \\
\text { over }\end{array}$ \\
\hline Province of Milan & $4,4 \%$ & $8,3 \%$ & $4,3 \%$ & $5,3 \%$ & $16,3 \%$ & $29,8 \%$ & $13,5 \%$ & $10,6 \%$ & $7,6 \%$ \\
City of Milan & $3,9 \%$ & $6,9 \%$ & $3,5 \%$ & $4,7 \%$ & $16,0 \%$ & $28,0 \%$ & $14,3 \%$ & $12,5 \%$ & $10,3 \%$ \\
Province of Milan excluding & $4,7 \%$ & $9,0 \%$ & $4,7 \%$ & $5,6 \%$ & $16,4 \%$ & $30,7 \%$ & $13,0 \%$ & $9,6 \%$ & $6,2 \%$ \\
the City of Milan & Source: Italian National Statistical Office (ISTAT) & -2001 Census & &
\end{tabular}

Summing up, the macro evidence suggests that the urban region of Milan is experiencing a deep process of change: on the one hand we can see the core city acquiring more and more the role of a "platform" for activities - from business to leisure - which is working quite efficiently but is oppressing the living conditions of the resident population. On the other hand we can see that the population living in Milan is changing its composition and its distribution across the urban region: the resident population of the core city is aging, with a limited replacement by the young living outside but working in the city, while the share of immigrants is increasing, attracted by the booming economy. We know that this profound transformations are causing contradictory effects: while the quality of life seems worsening for the resident population due to traffic congestion, air pollution and conflicts between residents and city users (Martinotti 1993), housing prices continue to increase yielding so far a financial return higher than any equity in the stock exchange, indicating indirectly that living in Milan continues to be somehow attracting.

In our opinion, this may explain the apparent contradictory opinions expressed by the Milan sample in the GMS. They have witnessed a quick transformation of their territory without being protagonists. Most of the resident population do not take direct advantage of greater opportunities, and if any they have seen a worsening of their life conditions: higher housing prices, longer commuting times, heavier pollution. Therefore they may be proud of living around such a stimulating environment, but their actual life condition are much less satisfying. This may explain why the reported well-being is much lower than their city pride.

\section{Policies to improve Citizens’ Well-Being in Milan}

This deep transformation in the structure and in the form of the Milan metropolitan area has raised three main issues in the scientific and political debate. The first one is the problem of infrastructures. This rapid development has occurred without a real capacity of national, regional and/or local governments to provide effective policies to support the mobility in the most economically vital area of the country (OECD 2006). The railway system is more or less the same of the beginning of the 20th century, while the highway system was completed in the 1970s and there have been some progress only in the development of the underground system of the core city. In the most recent years these themes have gained momentum in political and economic circles, where the lack of adequate infrastructures (roads and public transport) is almost unanimously recognised. Local authorities seem now to realize it while trying to gather funding and consensus, two problems not easy to be solved jointly and at the same time. According to our previous results from surveys, the capability to move is perceived as improving the network of personal ties, and therefore associated to higher well-being.

The second issue is the metropolitan governance (OECD 2006). It is by now clear that the traditional administrative structure is completely inadequate to cope with problems which go far beyond the borders and the traditional catchments areas of local policies. Many attempts in the past to solve the problem of establishing a new metropolitan level of government have failed (Balducci 2003). It is 
possible to notice a slow but progressive growth in the awareness that a new institutional design should be based upon voluntary cooperation between existing institutions rather than upon a legislative imposition of an institutional re-design of the local government structure. The governance context is so complex that no simple formula can try to put some order in it. However, looking at the perception of the citizenships, the administration quality does not correlate with subjective well-being though it raises the pride of the local inhabitants.

A third important issue which now calls for open discussion is the quality of life. It is widely recognised that over the last twenty years Milan has succeeded in passing through profound economic changes and overcoming their potentially dramatic effects, but this has been done by sacrificing the equilibrium of its environment and its liveability. There is an obvious connection with the two previous themes, the infrastructural crisis and the metropolitan governance problem. Quality of life is deeply affected by pollution and traffic congestion, which are in turn strongly linked to an inadequate public and private transport system. But it is also linked to the governance fragmentation, which brought about uncontrolled development across the urban region. This theme is getting a growing importance in the scientific debate and in the media, while political actors are quite reluctant in addressing it with robust policies. Only recently the Provincial government, a rather weak actor in the administrative structure of local government, has proposed a strategic project centred upon the notion of LIVEABILITY. Its main argument is that achieving higher levels of liveability, in the new conditions of the economic and social evolution of the urban region, must be considered a strategic objective, both for people and for enterprises (Provincia di Milano 2007).

Interestingly enough in this project the Province proposes six different meanings of liveability, covering various aspects of what is nowadays considered critical in Milan (Provincia di Milano 2007). These themes have significant overlapping with those covered by GMS survey. Here is the list of these not mutually excluding aspects:

(1) RESIDING. House finding; changing and transforming; stable or temporary residing; being welcomed and welcoming; staying at home and out, alone and with others.

(2) MOVING AND BREATHING. Free moving with different transport means, in different directions; comfortable waiting spaces; reducing pollution, making the environment healthier and creating the conditions for better breathing.

(3) SPACES SHARING. Connecting people in places; offering silent spaces and opportunity to slow down; to multiply meeting places and give chance to unexpected practices; creating conditions of natural and green contexts.

(4) MAKING CULTURE AND USING IT. Enjoying and being stimulated by various opportunities; promoting culture in various places; multiplying learning opportunities and artistic activities.

(5) PROMOTING A NEW LOCAL WELFARE. Valuing voluntary activities and practices of solidarity; favouring citizens' involvement; networking and making social services more affordable; supporting families who face difficulties.

(6) INNOVATING AND MAKING ENTERPRISE. Being supportive in innovation and creation of new enterprises; building society and territory at the same time; rooting enterprises; favouring connections with global networks.

If we consider all these aspects of liveability, reflecting upon the situation described in the first part of this article, we can say that in most of the liveability dimensions the Milan metropolitan area has regressed over the last 20 years. This is true for RESIDING, due to a speculative property market which has reduced rented and affordable housing to a minimum; for MOVING AND BREATHING, for the very high levels of pollution due to a congested private mobility; for SPACES SHARING, due to the conflicting uses of public spaces by residents and city users. A suspended judgement has to be assumed in relation to other dimensions where we can see signs of progress as for MAKING CULTURE AND USING IT, thanks to improved incomes and diffuse cultural vitality; for PROMOTING A NEW LOCAL WELFARE, due to the resistant welfare tradition and to the strength of voluntary associations, and 
finally for INNOVATING AND MAKING ENTERPRISE, due to the development of the knowledge economy.

Looking at the GMS survey, it is quite interesting to notice that all these different dimensions of liveability have been submitted to the attention of the sample with the results that we have already reported above. Milan's citizens are very worried about air pollution and safety in their city, they express a negative opinion also about the quality of public services and of their administration, while retaining a positive opinion only on the local economy and on community life. But all this sums up to one of the least happy population (even if not reflected into a negative position with respect to city pride). Our discussion shows that the different aspects of quality of life have a direct impact upon happiness and therefore should be considered in designing public policies. The novelty is that this is not only important for people happiness but also for economic competitiveness in a phase when the attraction of new talents and new firms is becoming a very important drive for the development of the knowledge economy. We could claim that in order to attract new talents, the new creative people who can boost innovation and wealth, a city administration has to offer the possibility of sharing some happy urban conditions, which in turn are linked to policies strengthening the quality of life: good public space, high quality amenities, mixture of arts and culture to produce exchange in a dense and free atmosphere.

We have seen that the critical aspects of Milan's liveability are also those which worry the sample of interviewees upon their perceived happiness. As a consequence we could easily conclude that the development of policies for the quality of life could be important not only to meet citizens expectations but also to improve city's attractiveness. In a phase in which world's metropolis compete to attract talents our survey says that the positioning of Milan is at risk of loosing them, at least as far as the quality of the urban environment is concerned. But the relative high level of city's pride measured in the survey suggests us another interesting implication: a high level of pride represents a capital of trust in the overall quality of the city which has not to be wasted. A further worsening of liveability could compromise this endowment, forcing more and more inhabitants to leave the city. Using the Albert Hirschman's well known sequence of exit, voice and loyalty (Hirschman 1970), we could say that a high level of pride is a sign of loyalty, that could stand a worsening of the leaving conditions up to the point when it leads to an exit choice. Milan's residents are using their voice option but so far public policies are not listening to it. But if we were to look at possible in-comers, the very mobile new talents (Florida 2008), they may be attracted by the economic vitality of the city; however, if the city is unable to offer a good quality of life, they can easily migrate to other better places. Here is where the connection between the citizens perception about happiness and pride and the need for public policies for the improvement of urban space becomes evident and could lead to strategic choices.

\section{CONCLUDING REMARKS}

In this paper we made use of an ad hoc survey on different aspects of city life conducted in 2006 in ten metropolitan areas of the developed word. We have investigated the relationship between eight indicators of quality of urban life and subjective well-being expressed by the interviewed citizens. We have shown that the subjective well-being is strongly correlated with the opportunity of personal relationships, which are given both by the town physical structure (availability of meeting places, accessibility of local shops, mobility) and by the existing social organisation of life (local meeting opportunities, volunteering).

We have also studied the association between life quality and pride of living in a specific city, finding a significant correlation with the cultural opportunities offered by a city, as well as by the good functioning of the local welfare provisions. By combining the results about well-being and pride, we have shown that there are some cities (definitively New York, but also Milan and Beijing) whose 
citizens seem constantly prouder of their cities, irrespective from their individual conditions or opinions.

When considering city-specific models of association between happiness and life quality, we confirmed the robustness of the global model, but we were unable to find consistent regional models of association. We then focussed on the case of Milan, where we have highlighted an apparent contradiction: local residents are proud of living in a city offering several cultural opportunities, without being able of taking advantage of them to raise their own well-being.

We have suggested an interpretation of this outcome by illustrating the recent changes undergone by the Milan area. The recent urban transformations have forced a large fraction of residents to adapt to different life-styles, living across the urban region and working downtown. Milanese citizens seem to combine two conflicting perceptions: on one side they are proud of residing in Milan, because the city offers greater cultural and welfare prospects; on the other side, they are less happy than they could have been accordingly (when compared to other cities). We read it as an implicit desire for a better quality of life. Political actors are implicitly or explicitly aware of this situation and nevertheless they do not address it with robust measures because they fear that this could negatively affect the economic health of the city. The outcome is a situation in which policies remain hesitant and inconsistent.

In our opinion this contradiction between pride and happiness in the city is still the projection of an attitude going back to the tradition of Milan as an industrial city. In the industrial era economic strength was independent, if not hostile to, the quality of life, opposing the world of producing to the world of living. In the current phase of the knowledge economy, a reconciliation of what the industrial city had to separate is not only possible but also necessary. If political actors are able to look ahead, they could see that growth must connect the expectations of economic development with those of the quality of the environment, the social cohesion and the cultural vitality of the city. More audacious policies addressing various low-scoring dimensions of the quality of urban life could improve the attractiveness of the city for key economic actors, but also could result in citizens still proud but happier. 


\section{References}

Balducci, A. 2003. Policies, Plans and Projects. Governing the city-region of Milan. in DISP, n. 152, Brereton, F., J.Clinch and S.Ferreira. 2006. Happiness, Geography and the Environment. University College Dublin PEP Discussion Paper n.06/04

CRESME 2006. Gli scenari della domanda residenziale nella provincial di Milano 2006-2015, Firenze, Alinea

Clark, A., E.Diener, Y.Georgellis and R.Lucas. 2006. Lags and Leads in Life Satisfaction: A Test of the Baseline Hypothesis. IZA Discussion Paper No. 2526

Diener, E., E.Suh, R.Lucas and H. Smith. 1999. Subjective Well-Being: Three Decades of Progress. Psychological Bulletin. 125(2): 276-303.

Di Tella, R. and R. MacCulloch. 2006. Some Uses of Happiness Data in Economics. Journal of Economic Perspectives 20(1): 25-46.

Easterlin, R. 1974. Does Economic Growth Improve the Human a lot? Some Empirical Evidence. in Nations and Households in Economic Growth: Essays in Honor of Moses Abramowitz. New York and London, Academic Press.

Easterlin, R. 2001. Income and happiness: towards a unified theory. Economic Journal 111: 465-84.

Florida, R. 2008. Who's your city? How the creative economy is making where to live the most important decision of your life. New York, Basic Books.

Foot, J. 2001. Milan since the Miracle. City, Culture, Identity, Berg, Oxford.

Frey, B.S., and A. Stutzer. 2002. Happiness in economics, Princeton University Press, Princeton.

Jacobs, J. 1962. The Death and Life of Great American Cities. London, Jonathan Cape.

Hirschman, A.O. 1970. Exit, Voice and Loyalty. Responses to Decline in Firms, Organisations and States. Cambridge (Mass.), Harvard University Press.

Lavalle et al. 2002. Towards an urban atlas, EC-JRC EEA, Brussels

Layard, R. 1980. Human Satisfactions and Public Policy. Economic Journal, Vol.90:737-50.

Layard, R. 2006. Happiness and public policy: a challenge to the profession. The Economic Journal, 116 (March): C24-C33

Layard, R., G.Mayraz and S.Nickell. 2008. The marginal utility of income. Journal of Public Economics 92: 1846-57

Lynch, K. 1981. A Theory of Good City Form, Cambridge Mass. The MIT Press.

Martinotti, G. 1993. Metropoli. La nuova morfologia sociale della città, Bologna, Il Mulino

OECD 2006. Territorial Review: Milan, Italy, Paris

Provincia di Milano 2007. Per la città abitabile. Scenari, visioni, idee, Milano, Assessorato al Piano strategico. 


\section{Appendix 1 - Additional tables}

Table A.1 - Determinants of happiness

\begin{tabular}{|c|c|c|c|c|c|c|}
\hline & $\begin{array}{c}1 \\
\text { ols }\end{array}$ & $\begin{array}{c}2 \\
\text { ols }\end{array}$ & $\begin{array}{c}3 \\
\text { ols } \\
\end{array}$ & $\begin{array}{c}4 \\
\text { oprobit } \\
\end{array}$ & $\begin{array}{c}5 \\
\text { oprobit } \\
\end{array}$ & $\begin{array}{c}6 \\
\text { oprobit } \\
\end{array}$ \\
\hline female & 0.12 & 0.109 & 0.096 & 0.168 & 0.161 & 0.142 \\
\hline & {$[4.15]^{\star * *}$} & {$[4.06]^{\star * *}$} & {$[3.50]^{\star * *}$} & {$[4.19]^{\star * *}$} & {$[4.15]^{\star * *}$} & {$[3.75]^{\star * *}$} \\
\hline age & -0.009 & -0.007 & -0.007 & -0.011 & -0.009 & -0.009 \\
\hline & {$[1.43]$} & {$[1.13]$} & {$[1.11]$} & {$[1.27]$} & {$[0.99]$} & {$[1.00]$} \\
\hline age2 & 0 & 0 & 0 & 0 & 0 & 0 \\
\hline & {$[1.92]^{*}$} & [1.49] & [1.38] & {$[1.71]^{*}$} & [1.33] & {$[1.26]$} \\
\hline educ==elementary school completed (6th grade) & -0.069 & -0.048 & -0.036 & -0.147 & -0.132 & -0.115 \\
\hline & {$[0.70]$} & {$[0.56]$} & {$[0.47]$} & {$[1.09]$} & {$[1.11]$} & {$[1.09]$} \\
\hline educ==junior high school completed (9th grade) & -0.225 & -0.207 & -0.209 & -0.341 & -0.339 & -0.349 \\
\hline & {$[2.42]^{* *}$} & {$[2.46]^{* *}$} & {$[2.98]^{* *}$} & {$[2.65]^{\star * *}$} & {$[2.97]^{* * *}$} & {$[3.62]^{\star * *}$} \\
\hline educ==high school completed (12th grade) & -0.203 & -0.147 & -0.198 & -0.304 & -0.247 & -0.326 \\
\hline & {$[2.13]^{*}$} & {$[1.64]$} & {$[2.25]^{*}$} & {$[2.42]^{* *}$} & {$[2.12]^{* *}$} & {$[2.76]^{\star * *}$} \\
\hline educ==trade/vocational school completed & -0.198 & -0.168 & -0.218 & -0.304 & -0.284 & -0.357 \\
\hline & {$[1.74]$} & {$[1.69]$} & {$[2.60]^{* *}$} & {$[1.87]^{*}$} & {$[2.05]^{* *}$} & {$[3.10]^{* * *}$} \\
\hline educ $==$ college/university student & -0.172 & -0.087 & -0.133 & -0.265 & -0.165 & -0.237 \\
\hline & {$[1.62]$} & {$[1.00]$} & {$[1.53]$} & {$[1.83]^{*}$} & {$[1.30]$} & {$[1.83]^{*}$} \\
\hline educ $==$ college/university completed or above & -0.196 & -0.13 & -0.212 & -0.303 & -0.231 & -0.357 \\
\hline & {$[2.16]^{*}$} & [1.52] & {$[2.66]^{* *}$} & {$[2.39]^{\star *}$} & {$[1.90]^{*}$} & {$[3.00]^{\star * *}$} \\
\hline occup==agriculture/fishery/forestry & 0.119 & 0.118 & 0.065 & 0.115 & 0.12 & 0.037 \\
\hline & [1.48] & {$[2.12]^{*}$} & {$[1.07]$} & {$[0.77]$} & {$[1.16]$} & {$[0.28]$} \\
\hline occup==self-employed & -0.052 & -0.044 & -0.112 & -0.077 & -0.068 & -0.152 \\
\hline & {$[0.67]$} & {$[0.67]$} & {$[1.60]$} & {$[0.79]$} & {$[0.81]$} & {$[1.73]^{*}$} \\
\hline occup==office workers & 0.005 & -0.018 & -0.051 & -0.005 & -0.036 & -0.066 \\
\hline & [0.08] & {$[0.28]$} & {$[0.77]$} & {$[0.06]$} & {$[0.42]$} & {$[0.77]$} \\
\hline occup==manual workers & -0.14 & -0.152 & -0.202 & -0.173 & -0.197 & -0.265 \\
\hline & {$[1.78]$} & {$[2.06]^{*}$} & {$[2.60]^{* *}$} & {$[1.86]^{*}$} & {$[2.07]^{* *}$} & {$[2.56]^{* *}$} \\
\hline occup==skilled workers & -0.007 & -0.005 & -0.087 & -0.009 & -0.008 & -0.112 \\
\hline & {$[0.09]$} & {$[0.07]$} & {$[1.04]$} & {$[0.10]$} & {$[0.08]$} & [1.08] \\
\hline occup==-professional & -0.006 & -0.022 & -0.103 & -0.019 & -0.041 & -0.149 \\
\hline & {$[0.09]$} & {$[0.30]$} & {$[1.34]$} & {$[0.23]$} & {$[0.43]$} & {$[1.55]$} \\
\hline occup==sales & -0.021 & 0.015 & -0.057 & -0.028 & 0.022 & -0.069 \\
\hline & {$[0.21]$} & {$[0.16]$} & {$[0.69]$} & {$[0.22]$} & {$[0.18]$} & {$[0.64]$} \\
\hline occup==student & 0.065 & 0.058 & 0.012 & 0.063 & 0.056 & 0.002 \\
\hline & {$[0.76]$} & {$[0.66]$} & {$[0.13]$} & {$[0.56]$} & {$[0.46]$} & {$[0.01]$} \\
\hline occup==housewife & -0.054 & 0.038 & -0.029 & -0.111 & 0.014 & -0.062 \\
\hline & {$[0.56]$} & {$[0.57]$} & {$[0.40]$} & {$[0.88]$} & {$[0.15]$} & {$[0.69]$} \\
\hline occup==-unemployed & -0.056 & -0.06 & -0.12 & -0.06 & -0.067 & -0.141 \\
\hline & {$[0.64]$} & {$[0.72]$} & [1.29] & {$[0.57]$} & {$[0.66]$} & {$[1.24]$} \\
\hline health==very bad & -0.566 & -0.517 & -0.542 & -0.569 & -0.523 & -0.561 \\
\hline & {$[3.26]^{\star * *}$} & {$[2.94]^{* *}$} & {$[3.27]^{\star * *}$} & {$[3.09]^{* * *}$} & {$[2.69]^{* * *}$} & {$[3.11]^{\star * *}$} \\
\hline health==bad & -0.365 & -0.313 & -0.322 & -0.406 & -0.35 & -0.362 \\
\hline & {$[3.10]^{\star *}$} & {$[2.74]^{\star *}$} & {$[2.90]^{\star *}$} & {$[3.18]^{\star * *}$} & {$[2.76]^{\star * *}$} & {$[2.91]^{\star * *}$} \\
\hline health $==$ good & 0.324 & 0.266 & 0.257 & 0.396 & 0.329 & 0.32 \\
\hline & {$[9.96]^{\star * *}$} & {$[10.33]^{* * *}$} & {$[10.75]^{* * *}$} & {$[11.02]^{\star * *}$} & {$[13.56]^{* * *}$} & {$[10.77]^{\star * *}$} \\
\hline health==very good & 0.639 & 0.52 & 0.507 & 0.891 & 0.757 & 0.743 \\
\hline & {$[14.33]^{\star * *}$} & {$[13.59]^{\star * *}$} & {$[13.81]^{\star * *}$} & {$[12.74]^{\star * *}$} & {$[12.83]^{\star * *}$} & {$[12.40]^{\star * *}$} \\
\hline income==very low income & -0.398 & -0.357 & -0.353 & -0.446 & -0.401 & -0.4 \\
\hline & {$[4.74]^{\star * *}$} & {$[4.89]^{\star * *}$} & {$[4.68]^{\star * *}$} & {$[4.46]^{\star * *}$} & {$[4.44]^{* * *}$} & {$[4.26]^{\star * *}$} \\
\hline income==low income & -0.195 & -0.159 & -0.16 & -0.24 & -0.199 & -0.201 \\
\hline & {$[4.39]^{\star * *}$} & {$[3.83]^{* * *}$} & {$[3.79]^{\star * *}$} & {$[4.66]^{\star * *}$} & {$[3.93]^{\star * *}$} & {$[3.92]^{\star * *}$} \\
\hline income==high income & 0.163 & 0.124 & 0.116 & 0.256 & 0.212 & 0.205 \\
\hline & {$[6.72]^{\star * *}$} & {$[5.44]^{* * *}$} & {$[5.17]^{\star * *}$} & {$[6.22]^{\star * *}$} & {$[5.43]^{\star * *}$} & {$[5.56]^{\star * *}$} \\
\hline income==very high income & 0.308 & 0.244 & 0.217 & 0.571 & 0.502 & 0.464 \\
\hline & {$[2.66]^{* *}$} & {$[2.21]^{*}$} & {$[1.90]^{*}$} & {$[2.93]^{* * *}$} & {$[2.62]^{\star * *}$} & {$[2.34]^{* *}$} \\
\hline marital==single, never married & $\begin{array}{c}-0.215 \\
{[2.94]^{* *}}\end{array}$ & $\begin{array}{c}-0.169 \\
{[2.89]^{* *}}\end{array}$ & $\begin{array}{c}-0.15 \\
{[2.62]^{* *}}\end{array}$ & $\begin{array}{c}-0.295 \\
{[2.79]^{\star * *}}\end{array}$ & $\begin{array}{c}-0.242 \\
{[2.77]^{* * *}}\end{array}$ & $\begin{array}{c}-0.213 \\
{[2.56]^{* *}}\end{array}$ \\
\hline marital==married & -0.062 & 0.007 & 0.051 & -0.09 & 0.004 & 0.074 \\
\hline
\end{tabular}




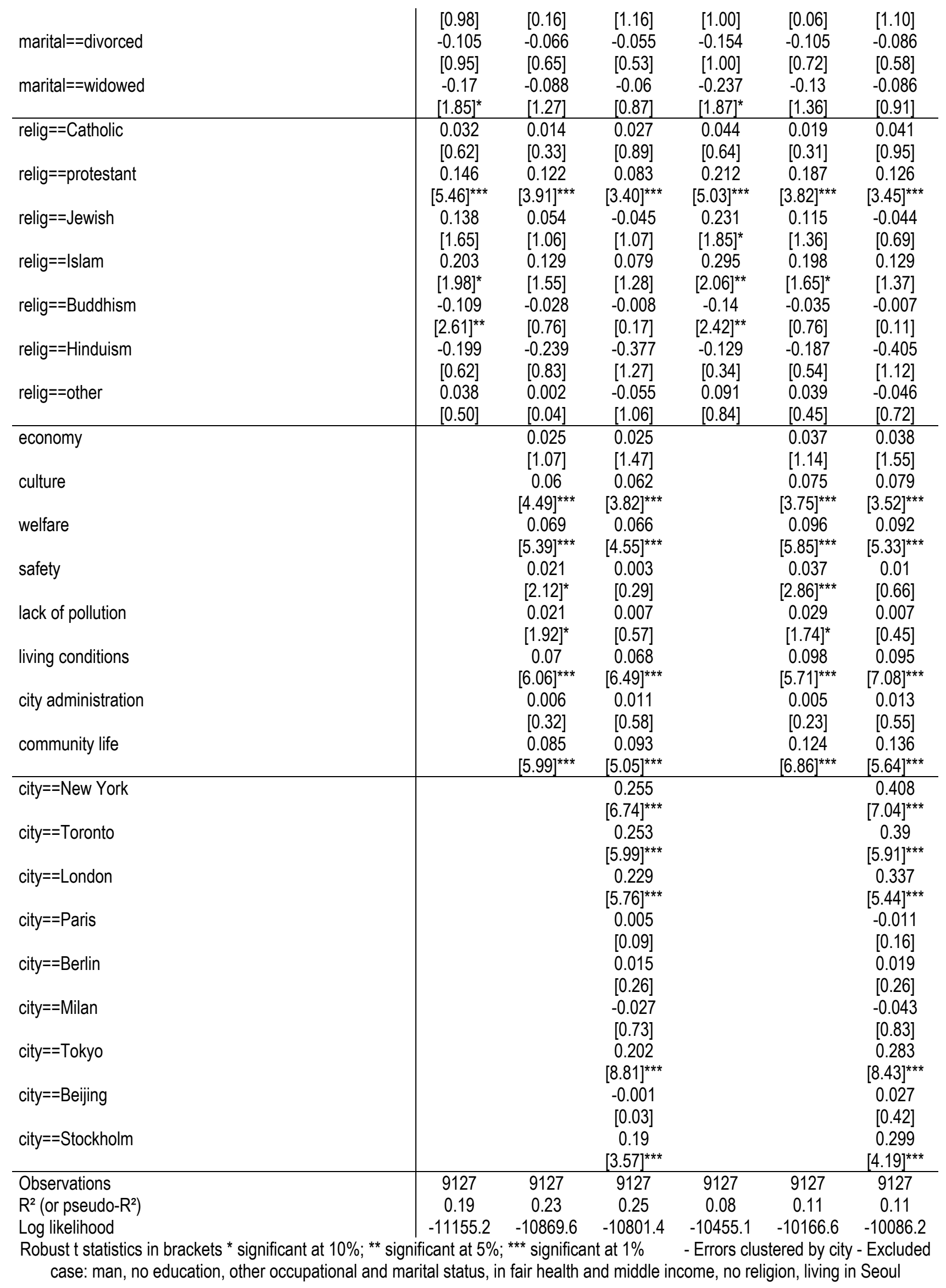


Table A.2 - Determinants of city pride

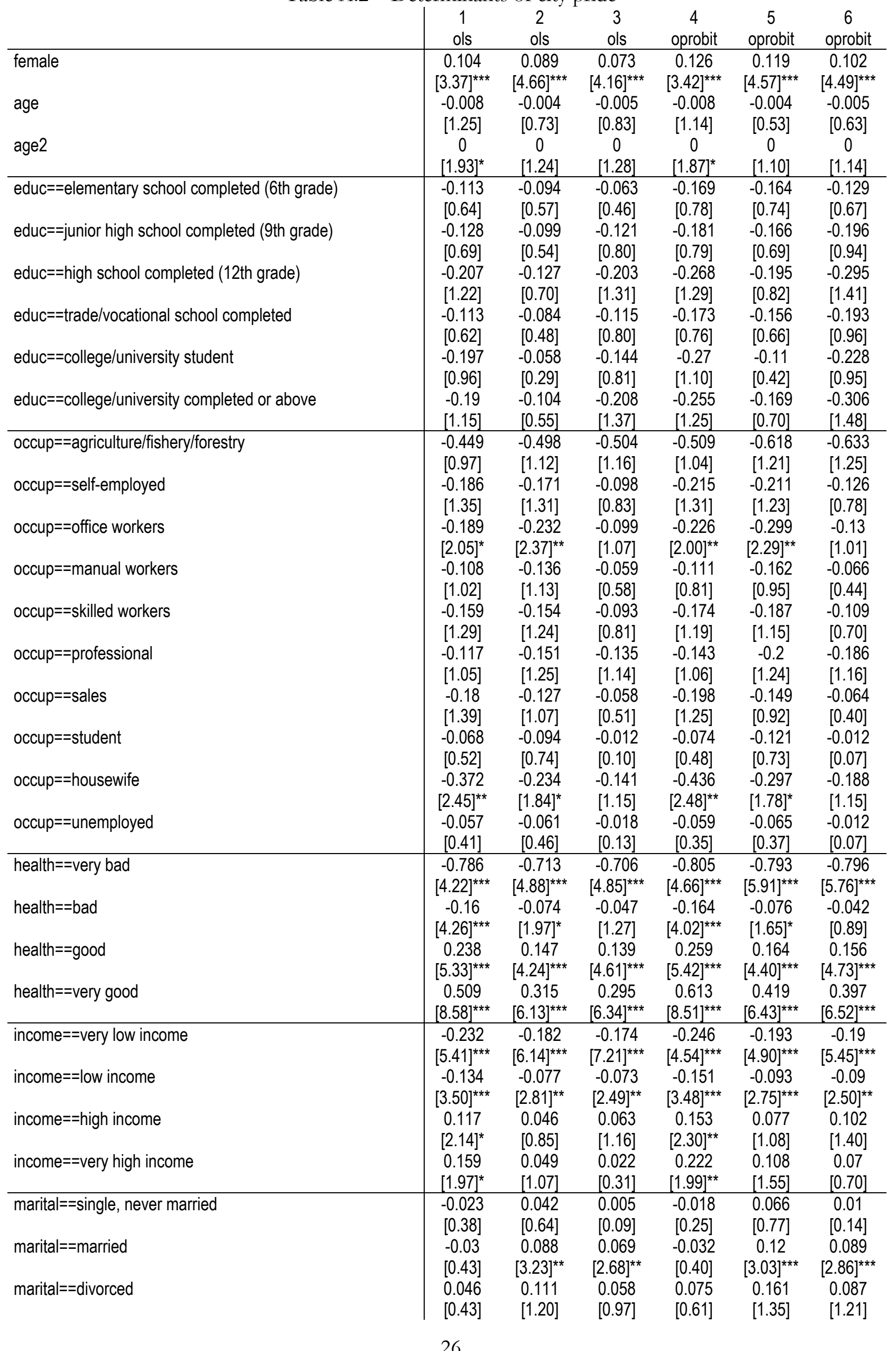




\begin{tabular}{|c|c|c|c|c|c|c|}
\hline marital==-widowed & $\begin{array}{l}0.009 \\
{[0.12]}\end{array}$ & $\begin{array}{c}0.14 \\
{[2.64]^{\star *}}\end{array}$ & $\begin{array}{c}0.101 \\
{[2.56]^{\star *}}\end{array}$ & $\begin{array}{l}0.013 \\
{[0.14]}\end{array}$ & $\begin{array}{c}0.183 \\
{[2.39]^{* *}}\end{array}$ & $\begin{array}{c}0.126 \\
{[2.30]^{\star *}}\end{array}$ \\
\hline relig==catholic & $\begin{array}{c}0.165 \\
{[2.75]^{* *}}\end{array}$ & $\begin{array}{c}0.156 \\
{[3.59]^{* * *}}\end{array}$ & $\begin{array}{c}0.091 \\
{[1.86]^{*}}\end{array}$ & $\begin{array}{c}0.204 \\
{[2.82]^{\star \star *}}\end{array}$ & $\begin{array}{c}0.211 \\
{[3.63]^{* * *}}\end{array}$ & $\begin{array}{c}0.132 \\
{[2.06]^{* *}}\end{array}$ \\
\hline relig==protestant & $\begin{array}{c}0.099 \\
{[2.08]^{*}}\end{array}$ & $\begin{array}{l}0.062 \\
{[1.16]}\end{array}$ & $\begin{array}{l}0.053 \\
{[1.61]}\end{array}$ & $\begin{array}{c}0.118 \\
{[1.96]^{* *}}\end{array}$ & $\begin{array}{l}0.083 \\
{[1.15]}\end{array}$ & $\begin{array}{l}0.066 \\
{[1.47]}\end{array}$ \\
\hline relig==jewish & $\begin{array}{c}0.471 \\
{[4.17]^{\star \star *}}\end{array}$ & $\begin{array}{c}0.355 \\
{[7.55]^{\star \star \star}}\end{array}$ & $\begin{array}{c}0.108 \\
{[3.42]^{\star \star *}}\end{array}$ & $\begin{array}{c}0.641 \\
{[3.65]^{\star * \star}}\end{array}$ & $\begin{array}{c}0.545 \\
{[5.68]^{\star * \star}}\end{array}$ & $\begin{array}{c}0.189 \\
{[4.50]^{* * *}}\end{array}$ \\
\hline relig==islam & $\begin{array}{c}0.547 \\
{[6.75]^{\star * *}}\end{array}$ & $\begin{array}{c}0.428 \\
{[7.49]^{* * *}}\end{array}$ & $\begin{array}{c}0.366 \\
{[4.78]^{* * *}}\end{array}$ & $\begin{array}{c}0.714 \\
{[6.61]^{\star * *}}\end{array}$ & $\begin{array}{c}0.606 \\
{[7.27]^{* * *}}\end{array}$ & $\begin{array}{c}0.533 \\
{[5.32]^{\text {*** }}}\end{array}$ \\
\hline relig==buddhism & $\begin{array}{l}-0.158 \\
{[1.56]}\end{array}$ & $\begin{array}{l}-0.028 \\
{[0.53]}\end{array}$ & $\begin{array}{l}-0.013 \\
{[0.25]}\end{array}$ & $\begin{array}{l}-0.174 \\
{[1.63]}\end{array}$ & $\begin{array}{l}-0.025 \\
{[0.45]}\end{array}$ & $\begin{array}{l}-0.017 \\
{[0.30]}\end{array}$ \\
\hline relig==hinduism & $\begin{array}{l}0.376 \\
{[1.00]}\end{array}$ & $\begin{array}{l}0.315 \\
{[0.76]}\end{array}$ & $\begin{array}{l}0.082 \\
{[0.19]}\end{array}$ & $\begin{array}{l}0.471 \\
{[1.05]}\end{array}$ & $\begin{array}{l}0.417 \\
{[0.80]}\end{array}$ & $\begin{array}{l}0.108 \\
{[0.20]}\end{array}$ \\
\hline relig==other & $\begin{array}{l}0.067 \\
{[0.91]}\end{array}$ & $\begin{array}{l}0.019 \\
{[0.27]}\end{array}$ & $\begin{array}{c}-0.056 \\
{[1.34]}\end{array}$ & $\begin{array}{l}0.103 \\
{[1.19]}\end{array}$ & $\begin{array}{l}0.047 \\
{[0.53]}\end{array}$ & $\begin{array}{l}-0.058 \\
{[1.22]}\end{array}$ \\
\hline economy & & $\begin{array}{l}0.008 \\
{[0.28]}\end{array}$ & $\begin{array}{c}-0.002 \\
{[0.13]}\end{array}$ & & $\begin{array}{c}0.01 \\
{[0.27]}\end{array}$ & $\begin{array}{c}-0.002 \\
{[0.11]}\end{array}$ \\
\hline culture & & $\begin{array}{c}0.181 \\
{[5.91]^{\star \star \star}}\end{array}$ & $\begin{array}{c}0.193 \\
{[6.33]^{\star \star \star}}\end{array}$ & & $\begin{array}{c}0.216 \\
{[5.06]^{\star \star \star}}\end{array}$ & $\begin{array}{c}0.237 \\
{[5.86]^{* * *}}\end{array}$ \\
\hline welfare & & $\begin{array}{c}0.111 \\
{[4.78]^{\star \star \star}}\end{array}$ & $\begin{array}{c}0.097 \\
{[6.14]^{\star * *}}\end{array}$ & & $\begin{array}{c}0.138 \\
{[4.70]^{\star * *}}\end{array}$ & $\begin{array}{c}0.127 \\
{[6.08]^{* * *}}\end{array}$ \\
\hline safety & & $\begin{array}{c}0.064 \\
{[4.62]^{\star \star \star}}\end{array}$ & $\begin{array}{c}0.046 \\
{[3.66]^{\star \star *}}\end{array}$ & & $\begin{array}{c}0.089 \\
{[4.81]^{\star \star \star}}\end{array}$ & $\begin{array}{c}0.069 \\
{[4.28]^{* * *}}\end{array}$ \\
\hline lack of pollution & & $\begin{array}{l}0.006 \\
{[0.28]}\end{array}$ & $\begin{array}{l}0.016 \\
{[0.81]}\end{array}$ & & $\begin{array}{l}0.007 \\
{[0.22]}\end{array}$ & $\begin{array}{l}0.022 \\
{[0.82]}\end{array}$ \\
\hline living conditions & & $\begin{array}{c}0.081 \\
{[3.00]^{* *}}\end{array}$ & $\begin{array}{c}0.093 \\
{[4.11]^{* *}}\end{array}$ & & $\begin{array}{c}0.102 \\
{[2.91]^{\star * *}}\end{array}$ & $\begin{array}{c}0.121 \\
{[4.15]^{\star * *}}\end{array}$ \\
\hline city administration & & $\begin{array}{c}0.061 \\
{[2.73]^{\star *}}\end{array}$ & $\begin{array}{c}0.067 \\
{[3.51]^{\star * *}}\end{array}$ & & $\begin{array}{c}0.083 \\
{[3.15]^{\star \star *}}\end{array}$ & $\begin{array}{c}0.093 \\
{[3.92]^{* * *}}\end{array}$ \\
\hline community life & & $\begin{array}{c}0.065 \\
{[4.57]^{\star \star *}}\end{array}$ & $\begin{array}{c}0.063 \\
{[5.19]^{* *}}\end{array}$ & & $\begin{array}{c}0.087 \\
{[4.71]^{\star \star *}}\end{array}$ & $\begin{array}{c}0.089 \\
{[6.08]^{* * *}}\end{array}$ \\
\hline city==New York & & & $\begin{array}{c}0.494 \\
{[13.72]^{* * *}}\end{array}$ & & & $\begin{array}{c}0.682 \\
{[12.14]^{* * *}}\end{array}$ \\
\hline city==Toronto & & & $\begin{array}{c}0.394 \\
{[14.10]^{\star \star \star}}\end{array}$ & & & $\begin{array}{c}0.473 \\
{[9.85]^{\star \star *}}\end{array}$ \\
\hline city==London & & & $\begin{array}{c}0.244 \\
{[6.02]^{* \star *}}\end{array}$ & & & $\begin{array}{c}0.27 \\
{[5.30]^{* * *}}\end{array}$ \\
\hline city==Paris & & & $\begin{array}{l}0.033 \\
{[0.72]}\end{array}$ & & & $\begin{array}{l}-0.027 \\
{[0.51]}\end{array}$ \\
\hline city==Berlin & & & $\begin{array}{c}-0.154 \\
{[3.32]^{\star \star *}}\end{array}$ & & & $\begin{array}{c}-0.241 \\
{[4.41]^{* * *}}\end{array}$ \\
\hline city==Milan & & & $\begin{array}{c}0.168 \\
{[4.17]^{\star \star \star}}\end{array}$ & & & $\begin{array}{c}0.163 \\
{[2.66]^{\text {}}}\end{array}$ \\
\hline city==Tokyo & & & $\begin{array}{c}0.106 \\
{[3.12]^{* *}}\end{array}$ & & & $\begin{array}{c}0.091 \\
{[1.89]^{*}}\end{array}$ \\
\hline city==Beijing & & & $\begin{array}{c}0.19 \\
{[3.66]^{* \star *}}\end{array}$ & & & $\begin{array}{c}0.195 \\
{[3.13]^{* *}}\end{array}$ \\
\hline city==Stockholm & & & $\begin{array}{l}0.066 \\
{[1.27]} \\
\end{array}$ & & & $\begin{array}{l}0.025 \\
{[0.45]}\end{array}$ \\
\hline Observations & 9092 & 9092 & 9092 & 9092 & 9092 & 9092 \\
\hline$R^{2}$ (or pseudo- $R^{2}$ ) & 0.11 & 0.23 & 0.26 & 0.05 & 0.1 & 0.11 \\
\hline Log likelihood & -12202.3 & -11536.9 & -11384.3 & -11505.1 & -10848.5 & -10681.2 \\
\hline
\end{tabular}


Appendix 2 - The questionnaire

\section{Questionnaire : Quality of Life Survey}

${ }_{14}$ ID:

Hello, my name is

I'm working for

a research company as an interviewer. We are conducting a research project concerning some issues. Would you mind if I ask you a few questions for a moment?

AREA.

0) Seoul 1) NYC 2) Toronto 3) London 4) Paris 5) Berlin 6) Milan 7) Tokyo 8)Beijing 9) Stockholm 5

SQ1. Specify the gender 6

1) Male 2) Female (CHECK QUOTA)

SQ2. Could you please tell me your age? 7-8 (

) years old (CHECK QUOTA)

If less than 18 , thanks and terminate

- I will read some statements to you. Please tell me how much you agree or disagree with each statement using 5-point scale - strongly agree, agree, neither agree nor disagree, disagree, strongly disagree.

\begin{tabular}{|c|c|c|c|c|c|c|c|}
\hline & $\begin{array}{l}\text { Strongly } \\
\text { Agree }\end{array}$ & Agree & $\begin{array}{c}\text { Neither } \\
\text { Agree } \\
\text { Nor } \\
\text { Disagree }\end{array}$ & Disagree & $\begin{array}{l}\text { Strongly } \\
\text { Disagree }\end{array}$ & $\begin{array}{l}\text { Don't } \\
\text { Know }\end{array}$ & Refusal \\
\hline \multicolumn{8}{|c|}{ Economy } \\
\hline 1-1. There are plenty of job opportunities in my city. & & & & & & & \\
\hline 1-2. The price of living in my city is high. & & & & & & & \\
\hline \multicolumn{8}{|c|}{ Culture and Education } \\
\hline $\begin{array}{l}\text { 2-1. My city allows easy access to culture and leisure } \\
\text { facilities. }\end{array}$ & & & & & & & \\
\hline $\begin{array}{l}\text { 2-2. There are many things in my city that I can proudly } \\
\text { introduce to visitors. }\end{array}$ & & & & & & & \\
\hline $2-3$. I am satisfied with the quality of education in my city. & & & & & & & \\
\hline \multicolumn{8}{|l|}{ 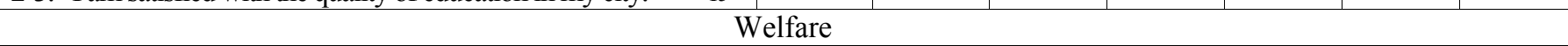 } \\
\hline $\begin{array}{l}\text { 3-1. In times of personal or family crisis, I can turn to the } \\
\text { city's public institutions and facilities for help. }\end{array}$ & & & & & & & \\
\hline 3-2. My city is a good place to rear and care for children. $\quad 15$ & & & & & & & \\
\hline $\begin{array}{l}\text { 3-3. My city has many facilities for the socially disadvantaged } 16 \\
\text { people such as the old, the handicapped, and the poor. }\end{array}$ & & & & & & & \\
\hline 3-4. I am satisfied with the quality of health care in my city. $\quad 17$ & & & & & & & \\
\hline \multicolumn{8}{|l|}{ 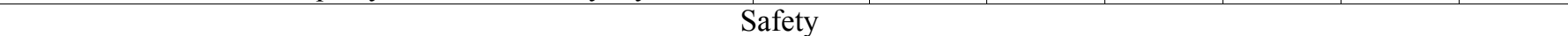 } \\
\hline 4-1. I feel safe walking around the city at night. & & & & & & & \\
\hline $\begin{array}{l}\text { 4-2. I feel safe from the danger of various accidents such as } \\
\text { car accidents, fires, and building collapses. }\end{array}$ & & & & & & & \\
\hline \multicolumn{8}{|c|}{ Environment } \\
\hline 5-1. I feel safe when I drink publicly provided water. & & & & & & & \\
\hline 5-2. Air pollution is a serious problem in my city. & & & & & & & \\
\hline \multicolumn{8}{|c|}{ Living conditions } \\
\hline \multicolumn{8}{|c|}{$\begin{array}{l}\text { 6-1. It is convenient to use public transportation e.g., subways, } 22 \\
\text { trains, or buses. in my city. }\end{array}$} \\
\hline \multicolumn{8}{|l|}{$\begin{array}{l}\text { 6-2. There are many places in my neighborhood or within } \\
\text { walking distance from the place that I live, where I can } \\
\text { sit and relax, or talk peacefully to neighbors and friends. }\end{array}$} \\
\hline \multicolumn{8}{|l|}{$\begin{array}{l}\text { 6-3. I can easily walk to buy groceries at shops in my } \\
\text { neighborhood or within walking distance to the place } \\
\text { that I live. }\end{array}$} \\
\hline \multicolumn{8}{|c|}{ City Administration } \\
\hline \multicolumn{8}{|c|}{\begin{tabular}{|l|l|l}
$7-1$. It is easy to get information about my city via internet. $\quad 25$ & &
\end{tabular}} \\
\hline \multicolumn{8}{|l|}{$\begin{array}{l}\text { 7-2. The city government does a good job addressing citizen } 26 \\
\text { concerns and requests. }\end{array}$} \\
\hline 7-3. The city administration is transparent. & & & & & & & \\
\hline \multicolumn{8}{|c|}{ Community Life } \\
\hline $\begin{array}{l}\text { 8-1. I try to have my friends or neighbors come over to my } \\
\text { home as frequently as possible. }\end{array}$ & & & & & & & \\
\hline $\begin{array}{l}\text { 8-2. There are many opportunities for volunteer activities in } \\
\text { my city. }\end{array}$ & & & & & & & \\
\hline
\end{tabular}


9. How is your health in general? (READ CODE 1-5) 30
1) Very good
2) Good
3) Fair
4) $\mathrm{Bad}$
5) Verybad
8) Don't Know (DO NOT PROMPT)
9) Refusal (DONOT PROMPT)

10. How proud are you of residing in the city? (READ CODE 1-5) 31
1) Very proud
2) Somewhat proud
3) Neither proud nor not proud
4) Not very proud
5) Not proud at all
8) Don't Know (DO NOT PROMPT)
9) Refusal (DONOT PROMPT)

11. How happy are you now? (READ CODE 1-5) 32
1) Very happy
2) Somewhat happy
3) Neither happy nor unhappy
4) Not very happy
5) Nothappy at all
8) Don't Know (DONOT PROMPT)
9) Refusal (DONOT PROMPT)

\section{Demographic Questions}

D1. Could you please tell me your education level? (READ CODE 1-7) 33
1) No education
2) Elementary school completed ( $6^{\text {th }}$ grade)
3) Junior high school completed ( $9^{\text {th }}$ grade)
4) High school completed ( $12^{\text {th }}$ grade)
5) Trade/Vocational school completed
6) College/University student
7) College/University completed or above
9) Refusal (DONOT PROMPT)

D2. What is the level of your household income? (READ CODE 1-5) 34

1) Very low income

2) Low income

3) Middle income

4) High income

5) Very high income

9) Refusal (DO NOT PROMPT)

D3. Could you please tell me your occupation? 35-36
1) Agriculture/fishery/forestry
2) Self-employed
3) Office workers
4) Manual workers
5) Skilled workers
6) Professional
7) Sales
8) Student
9) Housewife
10) Unemployed
11) Other (Please specify:
98) Don't Know
99) Refusal (DONOT PROMPT) 
D4. Could you please tell me your marital status? (READ CODE 1-5) 37
1) Single, never married
2) Married
3) Divorced
4) Widowed
5) Other
9) Refusal(DO NOT PROMPT)

D5. Could you please tell me your religion? 38
1) Catholic
2) Protestant
3) Jewish
4) Islam
5) Buddhism
6) Hinduism
7) Other
8) No religion
9) Refusal (DONOT PROMPT) 